\title{
Aqueous synthesis of Z-scheme photocatalyst powders and thin-film photoanodes from earth abundant elements
}

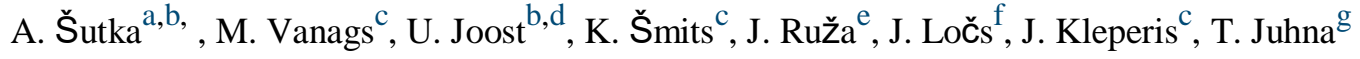 \\ ${ }^{a}$ Research Laboratory of Functional Materials Technologies, Faculty of Materials Science and Applied Chemistry, Riga Technical University, Paula Valdena 3/7, 1048 \\ Riga, Latvia \\ ${ }^{\mathrm{b}}$ Institute of Physics, University of Tartu, W. Ostwaldi Street 1, 50411, Tartu, Estonia \\ ${ }^{c}$ Institute of Solid State Physics, University of Latvia, Kengaraga 8, Riga LV-1063, Latvia \\ ${ }^{\mathrm{d}}$ Surface Science Group, Photonics Laboratory, Tampere University of Technology, PO BOX 692, FI-33101 Tampere, Finland \\ ${ }^{\mathrm{e}}$ Institute of Technical Physics, Faculty of Materials Science and Applied Chemistry, Riga Technical University, Paula Valdena 3/7, 1048 Riga, Lat via \\ ${ }^{\mathrm{f}}$ Rudolfs Cimdins Riga Biomaterials Innovations and Development Centre of RTU, Institute of General Chemical Engineering, Faculty of Materials Science and Applied \\ Chemistry, Riga Technical University, Pulka 3, 1007 Riga, Lat via \\ ${ }^{\mathrm{g}}$ Water Research Laboratory, Faculty of Civil Engineering, Riga Technical University, Ḳipsalas 6A, 1048 Riga, Latvia
}

\section{ARTICLE INFO}

\section{Keywords:}

Z-scheme

Photocatalyst

Hematite

Photoanode

Photoelectrochemical properties

\begin{abstract}
Solid-state narrow band gap semiconductor heterostructures with a Z-scheme charge-transfer mechanism are the most promising photocatalytic systems for water splitting and environmental remediation under visible light. Herein, we construct all-solid Z-scheme photocatalytic systems from earth abundant elements ( $\mathrm{Ca}$ and $\mathrm{Fe})$ using an aqueous synthesis proced ure. A novel Z-scheme two-component $\mathrm{Fe}_{2} \mathrm{O}_{3} / \mathrm{Ca}_{2} \mathrm{Fe}_{2} \mathrm{O}_{5}$ heterostructure is obtained in a straightforward manner by soaking various iron-containing nanoparticles (amorphous and crystalline) with $\mathrm{Ca}\left(\mathrm{NO}_{3}\right)_{2}$ and performing short (20 min) thermal treatments at $820{ }^{\circ} \mathrm{C}$. The obtained powder materials show high photocatalytic performances for methylene blue dye degradation under visible light $\left(45 \mathrm{~mW} / \mathrm{cm}^{2}\right)$, ex-hibiting a rate constant up to $0.015 \mathrm{~min}^{-1}$. The heterostructure exhibits a five-fold higher activity compared to that of pristine hematite. The experiments show that amorphous iron-containing substrate nanoparticles trigger the $\mathrm{Fe}_{2} \mathrm{O}_{3} / \mathrm{Ca}_{2} \mathrm{Fe}_{2} \mathrm{O}_{5}$ heterostructure formation. We extended our study to produce $\mathrm{Fe}_{2} \mathrm{O}_{3} / \mathrm{Ca}_{2} \mathrm{Fe}_{2} \mathrm{O}_{5}$ nanoheterostructure photoanodes via the electrochemical deposition of amorphous iron-containing sediment were used. The visiblelight $\left(15 \mathrm{~mW} / \mathrm{cm}^{2}\right)$ photocurrent increases from $183 \mu \mathrm{A} / \mathrm{cm}^{2}$ to $306 \mu \mathrm{A} / \mathrm{cm}^{2}$ after coupling hematite and $\mathrm{Ca}_{2} \mathrm{Fe}_{2} \mathrm{O}_{5}$. Notably, the powders and photoanodes exhibit distinct charge-transfer mechanisms evidenced by the different stabilities of the
\end{abstract} heterostructures under different working conditions.

\section{Introduction}

Visible-light photocatalysis is a green, reagent-free and zero-energy technology for energy harvesting and environmental remediation [1]. Photocatalysis is based on semiconductor oxides absorbing light with incident photon energy matching or exceeding the semiconductor's bandgap [2]. Absorbed photons excite electrons to the conduction band (CB) and leave an electron hole in the valence band (VB), thus creating photogenerated electronhole pairs. In combination with ambient water, the electron-hole pairs trigger the formation of $\mathrm{H}_{2}$ and $\mathrm{O}_{2}$ [3] or reactive oxygen species (ROS) with strong oxidation capacity for the degradation of organic substances [4].

Semiconductor photocatalysis has several disadvantages. First, the most excellent photocatalytic material, $\mathrm{TiO}_{2}$, does not absorb visible light and can only be excited by ultraviolet radiation [5]. Incorporating dopants, such as nitrogen [6], sulfur [7], carbon [8] or transition metals [9], into $\mathrm{TiO}_{2}$ can add visible-light activity, but the utilized synthesis methods generally have low yield, high cost, or high ecological impact. Additionally, the resulting photocatalytic activities may be limited [10].

Narrow band gap visible-light-absorbing semiconductors $\left(\mathrm{WO}_{3}, \mathrm{Fe}_{2} \mathrm{O}_{3}\right.$, $\mathrm{BiVO}_{4}$, etc.) have been demonstrated as promising candidates for photocatalysis [11-13], but nevertheless most have limited photo-catalytic efficiency due to the fast recombination of photogenerated charge carriers. Some narrow band gap photocatalysts, for example, $\mathrm{Ag}_{2} \mathrm{O}$ and $\mathrm{Cu}_{2} \mathrm{O}$, are especially active using visible light but are not stable [14,15] and suffer from photocorrosion.

One of the most effective strategies to decrease the overall 
recombination and to improve the photocatalytic efficiency or stability is to increase the spatial separation of photogenerated charge carriers by coupling semiconductor oxides with metal and/or other semi-conductors to form twoor three-component systems [16,17]. In the most common system, two semiconductors are coupled with mis-matched band edges, generating a potential slope at the interface, which causes electrons to migrate to the component with the more-positive $\mathrm{CB}$ edge and causes holes to transfer to the material with the more-negative VB edge. The main drawback of such a system is a de-crease of its (overall) redox potential [18].

The most promising photocatalytic materials are all-solid semi-conductor systems with a Z-scheme photogenerated charge-transfer mechanism [19]. Zscheme systems have been reported for water splitting [20], dye degradation [21] and $\mathrm{CO}_{2}$ conversion [22]. In Z-scheme systems, semiconductors with mismatched band edges are coupled via ohmic contact to position the $\mathrm{CB}$ and VB potentials of one semiconductor more negative than those of the other semiconductor [18]. Ohmic contact in a Z-scheme system triggers the recombination of electrons and electron holes with lower reduction or oxidation poten-tial, thus leaving more reducing electrons and more oxidative holes intact and providing enormously high redox potential for the visiblelight-active narrow band gap semiconductor system.

The main obstacles for Z-scheme practical applications are compli-cated (non-industrializable) multistep synthesis methods, small yields and expensive reagents. Moreover, often Z-scheme photocatalyst synthesis are not green, but photocatalysis technology can be fully considered as green if the green synthesis principles have been fol-lowed. Additionally, many involved materials are rare or toxic.

Here, we present a novel Z-scheme semiconductor photocatalyst system based on hematite $\mathrm{Fe}_{2} \mathrm{O}_{3}$ and brownmillerite $\mathrm{Ca}_{2} \mathrm{Fe}_{2} \mathrm{O}_{5}$ with excellent charge separation (reduced recombination), excellent visible-light harvesting ability and high redox potential. Both $\mathrm{Fe}_{2} \mathrm{O}_{3}$ and $\mathrm{Ca}_{2} \mathrm{Fe}_{2} \mathrm{O}_{5}$ consist from earth abundant elements and are narrow band gap semiconductors with band gap energy approximately $2 \mathrm{eV}$. Moreover, hematite is n-type semiconductor, but brownmillerite is p-type semiconductor, thus providing ohmic contact and avoiding addi-tional synthesis steps for depostion of electronic mediators between two semiconductors in Z-scheme. Hematite and brownmillerite also exhibit proper band gap positions as described below. The system was made using an aqueous synthesis to maintain green chemistry principles.

\section{Experimental section}

\subsection{Materials}

Iron (iii) nitrate nonahydrate $\left(\mathrm{Fe}\left(\mathrm{NO}_{3}\right)_{3} \cdot 9 \mathrm{H}_{2} \mathrm{O}\right.$, $\left.\geq 98 \%\right)$, hexamethylenetetramine (HMTA, $\mathrm{C}_{6} \mathrm{H}_{12} \mathrm{~N}_{4}, \geq 99 \%$ ), calcium nitrate tetra-hydrate $\left(\mathrm{Ca}\left(\mathrm{NO}_{3}\right)_{2} \cdot 4 \mathrm{H}_{2} \mathrm{O}, \geq 99 \%\right)$, sodium hydroxide $(\mathrm{NaOH}, \geq 98 \%)$, $\mathrm{MB}$, $\left.\mathrm{C}_{16} \mathrm{H}_{18} \mathrm{ClN}_{3} \mathrm{~S}, \geq 95 \%\right)$, BQ $\left(\mathrm{C}_{6} \mathrm{H}_{4}(=\mathrm{O})_{2}\right.$, certified reference mate-rial), TEA $\left(\left(\mathrm{HOCH}_{2} \mathrm{CH}_{2}\right)_{3} \mathrm{~N}, \geq 99 \%\right)$, and TBA $\left(\mathrm{C}_{4} \mathrm{H}_{10} \mathrm{O}\right.$, anhydrous, $\left.\geq 99.5 \%\right)$ were provided by Sigma-Aldrich and were used as received without performing additional purification steps. Deionized water (Milli-Q, electrical resistivity $18.2 \mathrm{M} \Omega \mathrm{cm}$ ) was used for the synthesis and photocatalytic tests.

\subsection{Synthesis of the nanoparticle substrates, powdered $\mathrm{Fe}_{2} \mathrm{O}_{3} / \mathrm{Ca}_{2} \mathrm{Fe}_{2} \mathrm{O}_{5}$ nanoheterostructures and photoanodes}

\subsubsection{Amorphous Fe-containing nanoparticles}

To synthesize the amorphous iron-based substrate nanoparticles, $0.1 \mathrm{M}$ iron(iii) nitrate was dissolved in deionized water. The obtained iron nitrate solution was mixed with a $0.5 \mathrm{M}$ HMTA aqueous solution at an equivolumetric ratio at room temperature. Brown sediment im-mediately formed after mixing the two solutions. After stirring for $5 \mathrm{~min}$, the sediment was collected by centrifugation and was washed with water until the $\mathrm{pH}$ value reached 7 . The obtained nanoparticle sediment for the heterostructure synthesis was kept in water without drying.

\subsubsection{Goethite $(\alpha-\mathrm{FeOOH})$}

Goethite $\alpha-\mathrm{FeOOH}$ nanowires were synthesized by chemical precipitation. In a typical procedure, a $0.1 \mathrm{M}$ iron(iii) nitrate aqueous so-lution was precipitated at room temperature by the dropwise addition of a $0.5 \mathrm{M}$ $\mathrm{NaOH}$ aqueous solution. The obtained sediments were stirred for an additional $30 \mathrm{~min}$ and aged for $72 \mathrm{~h}$ at $60{ }^{\circ} \mathrm{C}$. The obtained yellow goethite nanowires were collected using centrifugation, washed by water until neutral $\mathrm{pH}$ value and stored in water without drying.

\subsubsection{Hematite $\left(\alpha-\mathrm{Fe}_{2} \mathrm{O}_{3}\right)$}

Crystalline (colloidal) $\alpha-\mathrm{Fe}_{2} \mathrm{O}_{3}$ nanoparticles $\left(\mathrm{Fe}_{2} \mathrm{O}_{3} \quad(\mathrm{HU})\right)$ were synthesized by hydrothermal synthesis. During the synthesis, $40 \mathrm{ml}$ of a 0.1 $\mathrm{M}$ iron(iii) nitrate aqueous solution was poured into a $50 \mathrm{ml}$ Teflon-sealed stainless-steel autoclave and hydrothermally treated at $150{ }^{\circ} \mathrm{C}$ for $24 \mathrm{~h}$. As for the other nanoparticle substrates for the heterostructure synthesis, the nanoparticles were washed and stored in water without drying to prevent agglomeration.

\subsection{4. $\mathrm{Fe}_{2} \mathrm{O}_{3} / \mathrm{Ca}_{2} \mathrm{Fe}_{2} \mathrm{O}_{5}$ nanoheterostructure}

For the synthesis of the $\mathrm{Fe}_{2} \mathrm{O}_{3} / \mathrm{Ca}_{2} \mathrm{Fe}_{2} \mathrm{O}_{5}$ nanoheterostructures, various substrate nanoparticles were dispersed in a $\mathrm{Ca}\left(\mathrm{NO}_{3}\right)_{2}$ solution, filtered, dried at $60{ }^{\circ} \mathrm{C}$ and heat treated at $820{ }^{\circ} \mathrm{C}$ for $20 \mathrm{~min}$ in the ambient atmosphere. To control amount of $\mathrm{Ca}_{2} \mathrm{Fe}_{2} \mathrm{O}_{5}$, before filtering and annealing, the substrate nanoparticles were dispersed in $0.1 \mathrm{M}, 0.5 \mathrm{M}$ and $1 \mathrm{M}$ aqueous solutions of calcium nitrate.

\subsection{5. $\mathrm{Fe}_{2} \mathrm{O}_{3}$ and $\mathrm{Fe}_{2} \mathrm{O}_{3} / \mathrm{Ca}_{2} \mathrm{Fe}_{2} \mathrm{O}_{5}$ nanoheterostructure photoanodes}

The amorphous iron-containing substrate films were prepared by potentiostatic anodic electrodeposition on working electrodes - FTO-coated glass slides (surface resistivity $\sim 7 \Omega$ /sq, Sigma-Aldrich). Electrodeposition was performed from a $0.02 \mathrm{M} \mathrm{FeCl}_{2}$ aqueous solution using a Pt wire as the counter electrode by applying a potential of $1.2 \mathrm{~V}$. The deposition time and annealing temperature were $35 \mathrm{~min}$ and $40{ }^{\circ} \mathrm{C}$, respectively. To obtain the $\mathrm{Fe}_{2} \mathrm{O}_{3} / \mathrm{Ca}_{2} \mathrm{Fe}_{2} \mathrm{O}_{5}$ nanoheterostructure pho-toanode, amorphous ironcontaining substrate films were immersed in a $\mathrm{Ca}\left(\mathrm{NO}_{3}\right)_{2}$ solution, dried at 60 ${ }^{\circ} \mathrm{C}$ and heat treated at $820^{\circ} \mathrm{C}$ for $20 \mathrm{~min}$.

\subsection{Structural characterization}

The crystalline phases of the synthesized samples were analyzed by powder XRD. A Ultima+ diffractometer (Rigaku, Japan) with $\mathrm{Cu}-\mathrm{Ka}$ radiation was used for experiments. The SEM morphology studies were performed on a Helios Nanolab, FEI. Electron microscopy at high magnification was performed using TEM (Tecnai G2 F20, FEI) operated at $200 \mathrm{kV}$. To obtain better phase contrast of the different particles on the nanoheterostructures, STEM was used. EDX was used for sample elemental analysis to verify selected particles on the nanoheteros-tructures.

The specific surface areas of the synthesized powders were analyzed by recording nitrogen adsorption-desorption isotherms using a NOVA 1200e instrument (Quantachrome, UK). The specific surface areas, $\mathrm{S}\left(\mathrm{m}^{2} / \mathrm{g}\right)$, for the synthesized samples were calculated by the BET method. The surface charges (zeta potentials) of aqueous suspensions of hematite $(\sim 0.5 \mathrm{mg} / \mathrm{mL})$ were measured using a Zetasizer Nano ZSP (Malvern Instruments).

The optical absorption spectra of the samples in visible range were measured by a UV-NIR spectrophotometer (Agilent, Cary 4000 UV-vis, Germany). XPS was used to investigate the chemical states and ele-mental compositions of the heterostructure powders and photoanodes. The powders for XPS measurements were pressed in indium. A surface station equipped with an electron energy analyzer (SCIENTA SES 100) and a nonmonochromatic twin anode X-ray tube (Thermo XR3E2) with a characteristic energy of $1253.6 \mathrm{eV}(\mathrm{Mg} \mathrm{Ka1,2}$ FWHM $0.68 \mathrm{eV})$ were 

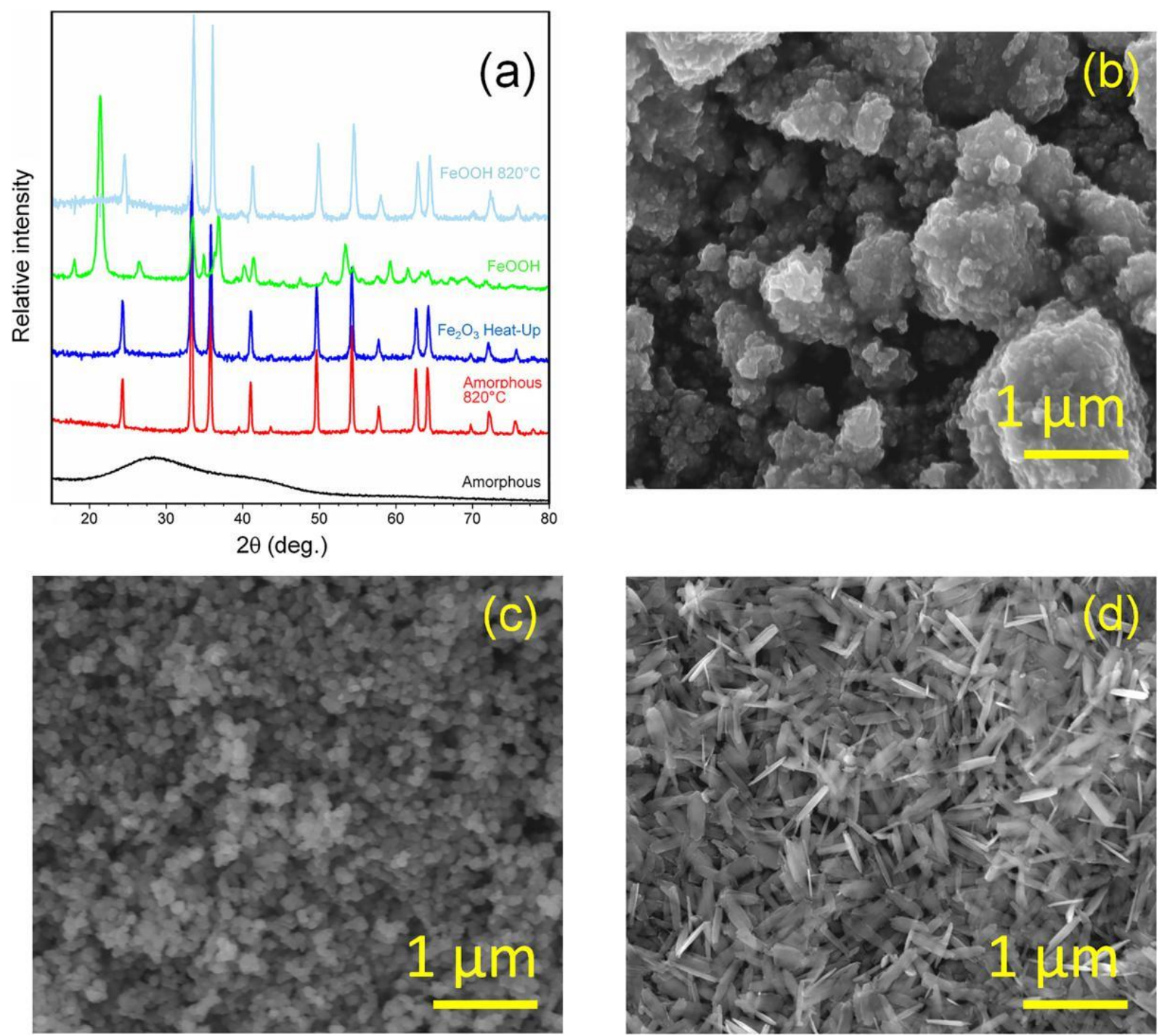

Fig. 1. XRD patterns (a) of different substrate nanoparticles before and after thermal treatment; SEM images of the as-prepared amorphous iron-containing substrate nanoparticles (b), $\mathrm{Fe}_{2} \mathrm{O}_{3}$ obtained by hydrothermal synthesis (c) and goethite nanowires (d).

used for XPS measurements. Ultra-high vacuum with a base-pressure lower than $8 \times 10^{-10}$ mbar was used for the XPS measurements. The binding energy was corrected in XPS experiments by using adventitious $\mathrm{C} 1 \mathrm{~s}$, CeC peak at $284.8 \mathrm{eV}$.

\subsection{Photocatalytic activity studies}

Photocatalytic activities and photocorrosion stabilities of the powder samples were estimated by the photocatalytic degradation of MB dye in aqueous solution (dye concentration $10 \mathrm{mg} / \mathrm{l}$, photocatalyst loading $1 \mathrm{mg} / \mathrm{mL}$ ) under visible-light irradiation. The light source used for experiments was a $100 \mathrm{~W}$ light-emitting diode (LED) (emission band approximately 415-700 $\mathrm{nm}$, i.e., $2.99 \mathrm{eV}$ to $1.77 \mathrm{eV}$ ) with an effective power density of $45 \pm 3$ $\mathrm{mW} / \mathrm{cm}^{2}$. The photocatalytic tests were per-formed at room temperature in closed $20 \mathrm{ml}$ glass vials. Constant stir-ring was provided during the tests.

Before the photocatalytic measurements, the powders were dis-persed in glass vials using a Hielscher UP50H Compact Lab Homogenizer at maximum intensity for $3 \mathrm{~min}$. The suspensions were kept in the dark until absorptiondesorption equilibrium was observed.

The photocatalytic degradation rate of MB was monitored by sam-pling $1.4 \mathrm{ml}$ from each suspension after a certain time interval. After centrifuging, the supernatant was analyzed by the spectrophotometer.
The photocatalytic activity was estimated by calculating the rate constant (k) of $\mathrm{MB}$ degradation from a pseudo-first-order reaction ki-netic equation, $-\ln \left(\mathrm{C}_{\mathrm{C}} \mathrm{C}_{0}\right)=\mathrm{kt}$, where $\mathrm{C}_{0}$ and $\mathrm{C}$ are the initial ab-sorption peak intensity of $\mathrm{MB}$ and the absorption peak intensity of MB in solution after a period of time (t). The rate constants $\mathrm{k}$ were divided by the BET surface area.

To estimate the photocorrosion stabilities, after the photocatalytic tests, the powders were separated by centrifugation, dried at $60{ }^{\circ} \mathrm{C}$ and re-dispersed again for the next measurement cycle.

\subsection{PEC measurements}

PEC measurements were measured in a three-electrode cell con-taining 1 $\mathrm{M} \mathrm{NaOH}$ electrolyte $(\mathrm{pH}=13)$, a platinum wire counter electrode, a sample film on an FTO/glass substrate as the working electrode $\left(1 \mathrm{~cm}^{2}\right)$ and SCE as the reference electrode. The open circuit potential was measured after $15 \mathrm{~min}$ in the dark. The photocurrent was measured using $5 \mathrm{~s}$ light pulses followed by $5 \mathrm{~s}$ in the dark with a VoltaLab PGZ 301 potentiostat (Radiometer Analytical) measuring the volt-amperic (I-V) curves (potential was scanned from -200 $\mathrm{mV}$ to $+500 \mathrm{mV}$ with a rate of $5 \mathrm{mV} / \mathrm{s}$ ). The photocurrent was calculated as the difference between currents in the dark and in the light for selected potential increments. After each sample, the electrolyte solution was 


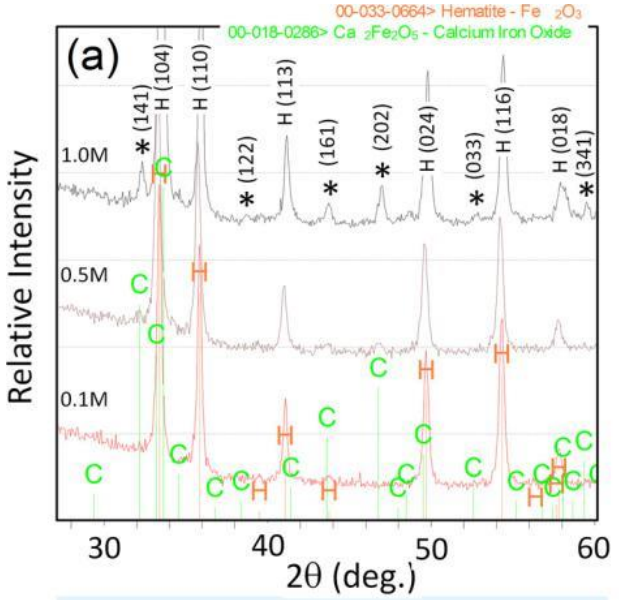

Spectrum 1

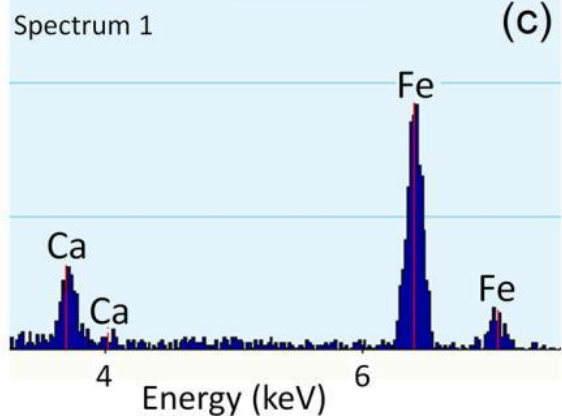

(c)

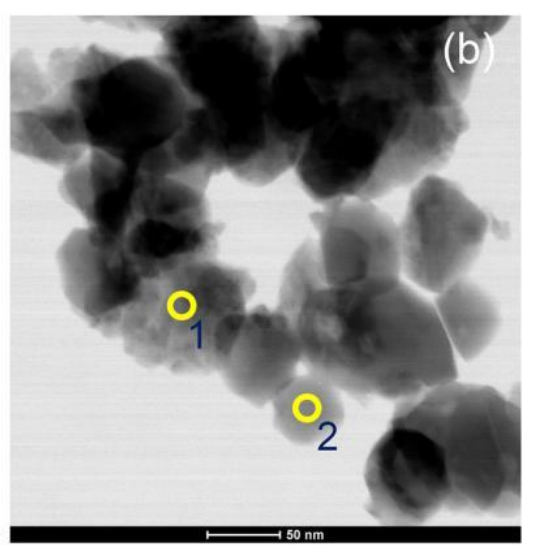

Fig. 2. Left upper panel shows the XRD patterns for the $\mathrm{Fe}_{2} \mathrm{O}_{3} / \mathrm{Ca}_{2} \mathrm{Fe}_{2} \mathrm{O}_{5}$ nanoheterostructures obtained from $\mathrm{Ca}\left(\mathrm{NO}_{3}\right)_{2}$ solutions with different molarities. The as-terisks on the XRD pattern relate to the brownmillerite phase, while $\mathrm{H}$ refers to the hematite phase. Right upper image shows a typical STEM micrograph of the $\mathrm{Fe}_{2} \mathrm{O}_{3} / \mathrm{Ca}_{2} \mathrm{Fe}_{2} \mathrm{O}_{5}$ nanoheterostructure. Selected areas for the EDX analysis are indicated in the STEM mi-crograph, and the corresponding EDX spectra are shown in the bottom left and right panels. changed, and the cell was rinsed with deionized water. The light source used for the PEC measurements was a $30 \mathrm{~W}$ LED with visible-light ir-radiation $\left(415-700 \mathrm{~nm}, 15 \pm 1 \mathrm{~mW} / \mathrm{cm}^{2}\right)$.

\subsection{Mott-Schottky analysis}

Fixed frequency $(10 \mathrm{kHz})$ impedance measurements using a VoltaLab PGZ 301 (Radiometer Analytical) impedance analyzer were performed to measure the Mott-Schottky curves. The capacitance was measured for each sample in a frequency of $10 \mathrm{kHz}$ at different biases from $-500 \mathrm{mV}$ to $300 \mathrm{mV}$ with a step of $50 \mathrm{mV}$. The measured capa-citance was plotted on a MottSchottky graph (1/C2 versus electrode potential) using the equation:

$$
\frac{1}{C^{2}}={ }_{e \varepsilon 0 \varepsilon N} V_{a p p}-V_{F B}-\frac{k T}{e}
$$

where $\mathrm{C}$ is the capacitance of the barrier layer, $\mathrm{V}_{\mathrm{app}}$ is the applied bias potential, $\mathrm{V}_{\mathrm{FB}}$ is the flat band potential, $\mathrm{N}$ is the concentration of donor charge carriers, and $\mathrm{T}$ is the absolute temperature. The VFB value was determined by extrapolating the linear region in the Mott-Schottky plot to zero.

\section{Results and discussion}

3.1. Iron-containing (substrate) nanoparticle formation and structural properties

Various iron-containing substrates were used for the preparation of $\mathrm{Fe}_{2} \mathrm{O}_{3} / \mathrm{Ca}_{2} \mathrm{Fe}_{2} \mathrm{O}_{5}$ nanoheterostructures. Nanosized particle substrates were dispersed in $\mathrm{Ca}^{2+}$-containing aqueous solution, filtered and heat treated. Upon heating, $\mathrm{Ca}^{2+}$ reacts with the iron species to form the $\mathrm{Fe}_{2} \mathrm{O}_{3} / \mathrm{Ca}_{2} \mathrm{Fe}_{2} \mathrm{O}_{5}$ nanoheterostructure. A similar strategy was demon-strated by K.J. McDonalds and K.S. Choi, where crystalline $\alpha-\mathrm{Fe}_{2} \mathrm{O}_{3}$ electrodes were immersed in $\mathrm{Zn}^{2+}$-containing solution and heat treated to obtain $\mathrm{Fe}_{2} \mathrm{O}_{3} / \mathrm{ZnFe}_{2} \mathrm{O}_{4}$ [23]. The tight interface between the semi-conductors in the nanoheterostructure enhances charge transfer and the photocatalytic performances [16,24]. If charge-carrier transfer/mobi-lity is hindered, electron and electron-hole pairs will be more likely to recombine [24]. Here, to achieve effective interfacial charge transfer between $\mathrm{Fe}_{2} \mathrm{O}_{3}$ and $\mathrm{Ca}_{2} \mathrm{Fe}_{2} \mathrm{O}_{5}$, various iron-containing nanoparticle substrates, such as amorphous precipitates and two crystalline sub-strates with different surface chemistry ( $\alpha-\mathrm{Fe}_{2} \mathrm{O}_{3}$ nanoparticles and $\alpha-\mathrm{FeOOH}$ nanowires), were tested. The formation of $\mathrm{Ca}_{2} \mathrm{Fe}_{2} \mathrm{O}_{5}$ should be easier on amorphous substrate nanoparticles. For crystalline materials, solid-state reactions are limited due to ion diffusion, while amorphous substrate nanoparticles serve as a site for the re-precipitation of a crystalline phase [25].

All the nanoparticle substrate materials were synthesized by environmentally friendly, scalable and straightforward aqueous chemistry methods. Amorphous iron-based substrate nanoparticles were obtained by mixing iron nitrate and hexamethylenetetramine (HMTA) water solutions at room temperature. The addition of the HMTA solution in-creases the $\mathrm{pH}$ of the ferric aqueous solution from 2.01 to 4.87 , and consequently, iron nitrate hydrolysis occurs. As confirmed by X-ray diffraction (XRD) measurements (Fig. 1(a)), amorphous precipitates form after mixing the precursors. The use of amorphous nanoparticle substrates is important for the synthesis of the $\mathrm{Fe}_{2} \mathrm{O}_{3} / \mathrm{Ca}_{2} \mathrm{Fe}_{2} \mathrm{O}_{5}$ nano-heterostructure immediately after the procedure (sedimentation and washing by water), as storage in water leads to the formation of iron oxide hydroxide, $\mathrm{FeO}(\mathrm{OH})$, crystals, as demonstrated by the XRD pat-tern in the Electronic Supplementary information (ESI), Fig. S1. Ad-ditionally, to obtain amorphous iron-containing nanoparticles, the ferric nitrate and HMTA solutions must be mixed at room temperature. Precipitation at higher temperatures triggers crystallization of $\alpha-\mathrm{FeOOH}$ and $\mathrm{a}_{-} \mathrm{Fe}_{2} \mathrm{O}_{3}$. ESI Fig. S2 presents the XRD plot for the sediment obtained upon mixing the ferric nitrate and HMTA solutions in water at $80{ }^{\circ} \mathrm{C}$, where the goethite and hematite phases are clearly distinguished. The microstructure of the sediment was studied by scanning electron microscopy (SEM) (Fig. 1(b), which revealed the formation of densely packed nanoparticle agglomerates with indeterminable particle size; however, the particle diameter is clearly estimated in the nanometer range. The relatively small particle size can be explained by the overall 

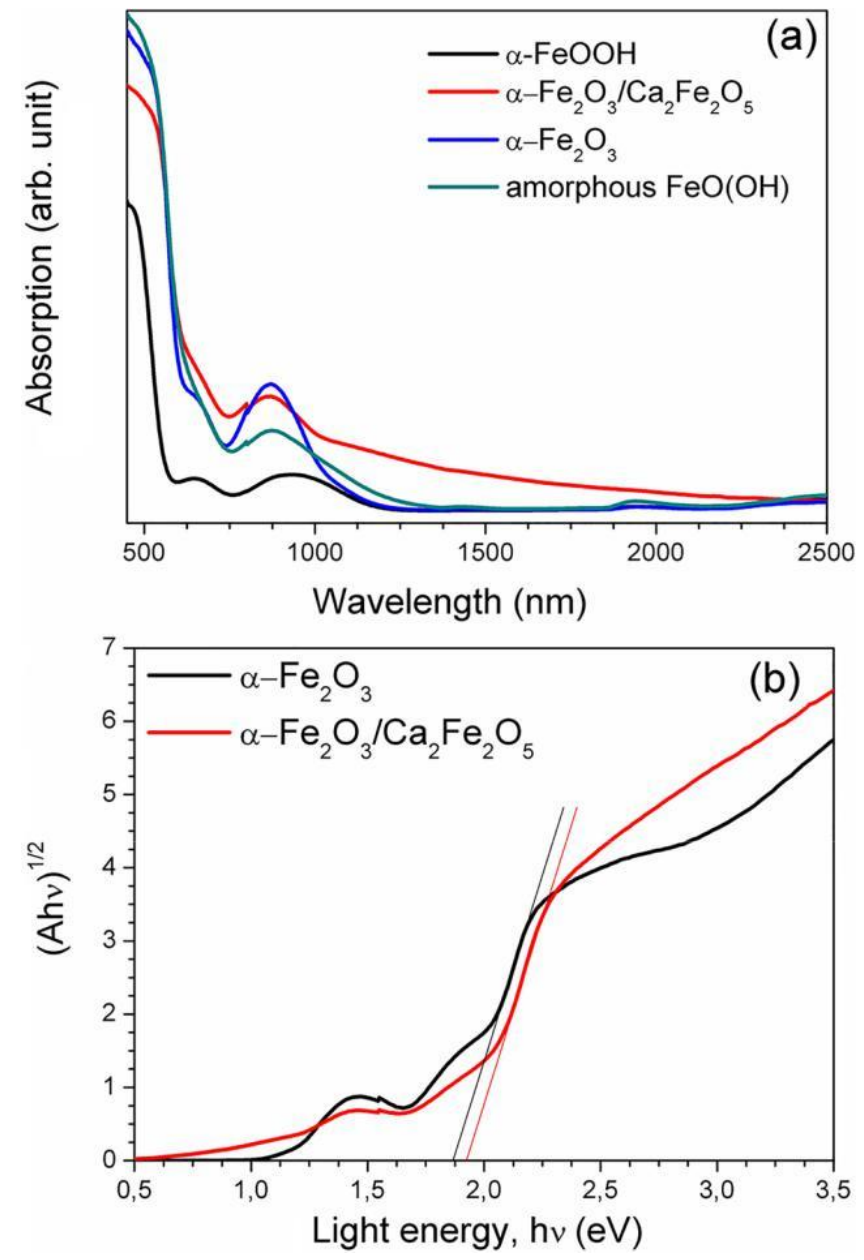

Fig. 3. UV-vis-NIR absorption spectra (Kubleka-Munk function) of various substrate nanoparticles and the $\mathrm{Fe}_{2} \mathrm{O}_{3} / \mathrm{Ca}_{2} \mathrm{Fe}_{2} \mathrm{O}_{5}$ nanoheterostructure (a); op-tical absorption ( $\alpha \mathrm{hv})^{1 / 2}$ versus photon energy plots for $\alpha-\mathrm{Fe}_{2} \mathrm{O}_{3}$ and the $\mathrm{Fe}_{2} \mathrm{O}_{3} / \mathrm{Ca}_{2} \mathrm{Fe}_{2} \mathrm{O}_{5}$ nanoheterostructure (b).

tendency to obtain smaller sized particles at lower synthesis tempera-tures. Heat treatment of the amorphous precipitate at $820{ }^{\circ} \mathrm{C}$ for $20 \mathrm{~min}$ yields the pure hematite $\mathrm{a}_{-} \mathrm{Fe}_{2} \mathrm{O}_{3}$ (A) (ICDD 00-006-0502) nano-particles, as demonstrated by the XRD pattern in Fig. 1(a), thus de-monstrating the potential to use the obtained precipitates to construct the hematite-based $\mathrm{Fe}_{2} \mathrm{O}_{3} / \mathrm{Ca}_{2} \mathrm{Fe}_{2} \mathrm{O}_{5}$ nanoheterostructure.

Crystalline (colloidal) $\alpha-\mathrm{Fe}_{2} \mathrm{O}_{3}(\mathrm{HU})$ nanoparticles were synthesized by a hydrothermal synthesis approach, where the $\mathrm{Fe}^{3+}$ nitrate solution in water was heated at $150{ }^{\circ} \mathrm{C}$ for $24 \mathrm{~h}$ for homogeneous nucleation, particle growth and $\mathrm{\alpha}-\mathrm{Fe}_{2} \mathrm{O}_{3}$ crystallization [26]. Phase-pure well-crystalline hematite was obtained immediately after the synthesis, as indicated by XRD (Fig. 1(a)), which shows a diffraction pattern with sharp hematite-related peaks (ICDD 00-006-0502) and no adjacent phases. SEM shows hematite particle formation with diameters from $10 \mathrm{~nm}$ up to $100 \mathrm{~nm}$ during the hydrothermal synthesis, as demon-strated in Fig. 1(c).

Goethite $\alpha-\mathrm{FeOOH}$ nanowires were obtained via the precipitation of iron nitrate by $\mathrm{NaOH}$ solution in water and aging for $72 \mathrm{~h}$ at $60{ }^{\circ} \mathrm{C}$. The precipitation synthesis yielded phase-pure goethite $\alpha-\mathrm{FeOOH}$ (ICDD 04-0152899) with a typical orthorhombic structure, as confirmed by XRD (Fig. 1(a)). The sharp diffraction peaks of the a-FeOOH nanowires in-dicate a wellcrystallized material. No peaks arising from impurities were detected by XRD. The formation of one-dimensional $\alpha-\mathrm{FeOOH}$ nanowires was confirmed by SEM (Fig. 1(d)). The synthesized nano-wires are up to $500 \mathrm{~nm}$ long, and the diameters vary from 20 to $150 \mathrm{~nm}$ with an aspect ratio up to 30 . Transmission electron microscopy (TEM) images (ESI, Fig. S3) show that most of the goethite nanowires are grouped in bundles, and the actual diameter of a single nanowire is approximately $21 \pm$ $5.5 \mathrm{~nm}$. The $\alpha-\mathrm{FeOOH}$ nanowires form during the precipitation synthesis by the olation of tetrameric polycation species to embryos of octahedral double chains, which is a characteristic of the goethite structure [27]. Goethite nanowires transform to phase-pure hematite $\alpha-\mathrm{Fe}_{2} \mathrm{O}_{3}(\mathrm{NW})$ upon annealing at $820^{\circ} \mathrm{C}$ for 20 min, as de-monstrated in Fig. 1(a).

\subsection{Formation and structural properties of $\mathrm{Fe}_{2} \mathrm{O}_{3} / \mathrm{Ca}_{2} \mathrm{Fe}_{2} \mathrm{O}_{5}$ nanoheterostructure powders}

Briefly, to obtain the $\mathrm{Fe}_{2} \mathrm{O}_{3} / \mathrm{Ca}_{2} \mathrm{Fe}_{2} \mathrm{O}_{5}$ nanoheterostructure, sub-strate nanoparticles were dispersed in $\mathrm{Ca}\left(\mathrm{NO}_{3}\right)_{2}$ solution, filtered, dried and thermally treated at $820{ }^{\circ} \mathrm{C}$ for $20 \mathrm{~min}$ in the ambient atmosphere. The amount of $\mathrm{Ca}_{2} \mathrm{Fe}_{2} \mathrm{O}_{5}$ can be controlled by molarity of $\mathrm{Ca}\left(\mathrm{NO}_{3}\right)_{2}$. Phases on the XRD pattern (Fig. 2(a) and ESI, Fig. S4) related to he-matite (ICDD 00033-0664) and brownmillerite $\mathrm{Ca}_{2} \mathrm{Fe}_{2} \mathrm{O}_{5}$ (ICDD 04-002-2559) were observed using the amorphous nanoparticle substrates. Increased peak intensities related to the $\mathrm{Ca}_{2} \mathrm{Fe}_{2} \mathrm{O}_{5}$ phase were observed upon increasing the molarity of the $\mathrm{Ca}\left(\mathrm{NO}_{3}\right)_{2}$ solution. The observed XRD pattern is in well accordance with the results from scanning transmission electron microscopy (STEM) and energy dispersive X-ray (EDX) spectroscopy analysis on single nanocrystals (Fig. 2(b-d)), which revealed the presence of both calcium and iron within the nanocrystal heterodimers, while only iron was observed on the hematite particle. The XRD peaks related to the $\mathrm{Ca}_{2} \mathrm{Fe}_{2} \mathrm{O}_{5}$ phase are not as strongly ob-served after the heat treatment of the $\mathrm{Ca}\left(\mathrm{NO}_{3}\right)_{2}$-soaked colloidal $\alpha-\mathrm{Fe}_{2} \mathrm{O}_{3}$ nanoparticles and goethite $\alpha-\mathrm{FeOOH}$ substrates (ESI, Fig. S5). Additionally, the presence of $\mathrm{Ca}^{2+}$ in the $\mathrm{Ca}\left(\mathrm{NO}_{3}\right)_{2}$-soaked and ther-mally treated $\alpha$ $\mathrm{FeOOH}$ is confirmed by the EDX studies presented in ESI, Fig. S6. Moreover, the $\mathrm{Ca}$ quantities in the heterostructures derived from the $\alpha-\mathrm{FeOOH}$ and amorphous iron-containing nanoparticles are very similar $(\sim 5 \mathrm{wt} \%)$. The amorphous iron-containing nanoparticle substrates could provide more surface sites and open pores and a higher surface area for precursor spatial infiltration and adsorption with a higher abundancy of $\mathrm{Fe}$ cations for $\mathrm{Ca}_{2} \mathrm{Fe}_{2} \mathrm{O}_{5}$ formation upon heat treatment. The surface of the goethite crystals presents a highly dense coating of $-\mathrm{OH}$ groups, and heating transforms goethite to $\mathrm{Fe}_{2} \mathrm{O}_{3}$ by releasing water based on the reaction: $2 \mathrm{FeOOH}$ $\rightarrow \mathrm{Fe}_{2} \mathrm{O}_{3}+\mathrm{H}_{2} \mathrm{O}$. Water release during the phase transition may prohibit $\mathrm{Fe}$ supply for $\mathrm{Ca}_{2} \mathrm{Fe}_{2} \mathrm{O}_{5}$ formation. The goethite wires also exhibit the lowest surface area among the substrate nanoparticles used for the $\mathrm{Fe}_{2} \mathrm{O}_{3} / \mathrm{Ca}_{2} \mathrm{Fe}_{2} \mathrm{O}_{5}$ nano-heterostructure synthesis. The multipoint Brunauer-Emmett-Teller (BET) specific surface area values for amorphous iron-containing sub-strates, crystalline $\alpha-\mathrm{Fe}_{2} \mathrm{O}_{3}$ and $\alpha-\mathrm{FeOOH}$ were $115.7 \mathrm{~m}^{2} / \mathrm{g}, 109.40 \mathrm{~m}^{2} / \mathrm{g}$ and 60.23 $\mathrm{m}^{2} / \mathrm{g}$, respectively.

3.3. Optical properties of the substrate nanoparticles and $\mathrm{Fe}_{2} \mathrm{O}_{3} / \mathrm{Ca}_{2} \mathrm{Fe}_{2} \mathrm{O}_{5}$ nanoheterostructure powders

Fig. 3 shows the UV-vis absorption spectra (Kubelka-Munk func-tion) of the $\mathrm{FeO}(\mathrm{OH}), \alpha-\mathrm{Fe}_{2} \mathrm{O}_{3}$ and $\alpha-\mathrm{FeOOH}$ substrate nanoparticles and the $\mathrm{Fe}_{2} \mathrm{O}_{3} / \mathrm{Ca}_{2} \mathrm{Fe}_{2} \mathrm{O}_{5}$ nanoheterostructure. All the materials exhibit (poorly defined) absorption bands centered at $650 \mathrm{~nm}$ and broad absorption bands in the wavelength range of 700-1000 nm, which cor-respond to the ${ }^{6} \mathrm{~A}_{1}\left({ }^{6} \mathrm{~S}\right) \rightarrow{ }^{4} \mathrm{~T}_{2}\left({ }^{4} \mathrm{G}\right)$ and ${ }^{6} \mathrm{~A}_{1}\left({ }^{6} \mathrm{~S}\right) \rightarrow{ }^{4} \mathrm{~T}_{1}\left({ }^{4} \mathrm{G}\right)$ ligand-field transitions of $\mathrm{Fe}^{3+}$, respectively [28]. The optical band gaps for he-matite $(1.86 \mathrm{eV})$ and for the $\mathrm{Ca}_{2} \mathrm{Fe}_{2} \mathrm{O}_{5} / \mathrm{Fe}_{2} \mathrm{O}_{3}$ nanoheterostructure $(1.92 \mathrm{eV})$ were observed from the optical absorption ( $\alpha \mathrm{hv})^{1 / 2}$ versus photon energy plots by extrapolating linear fits of the plots to zero [29]. The band gap values for hematite are usually dependent on the synth-esis method and have been reported to be between 1.9 to $2.2 \mathrm{eV}$ [30]. The observed blueshift for the heterostructure in comparison with he-matite is related to the higher band gap (2.2 eV) of pristine $\mathrm{Ca}_{2} \mathrm{Fe}_{2} \mathrm{O}_{5}$ [31]. 

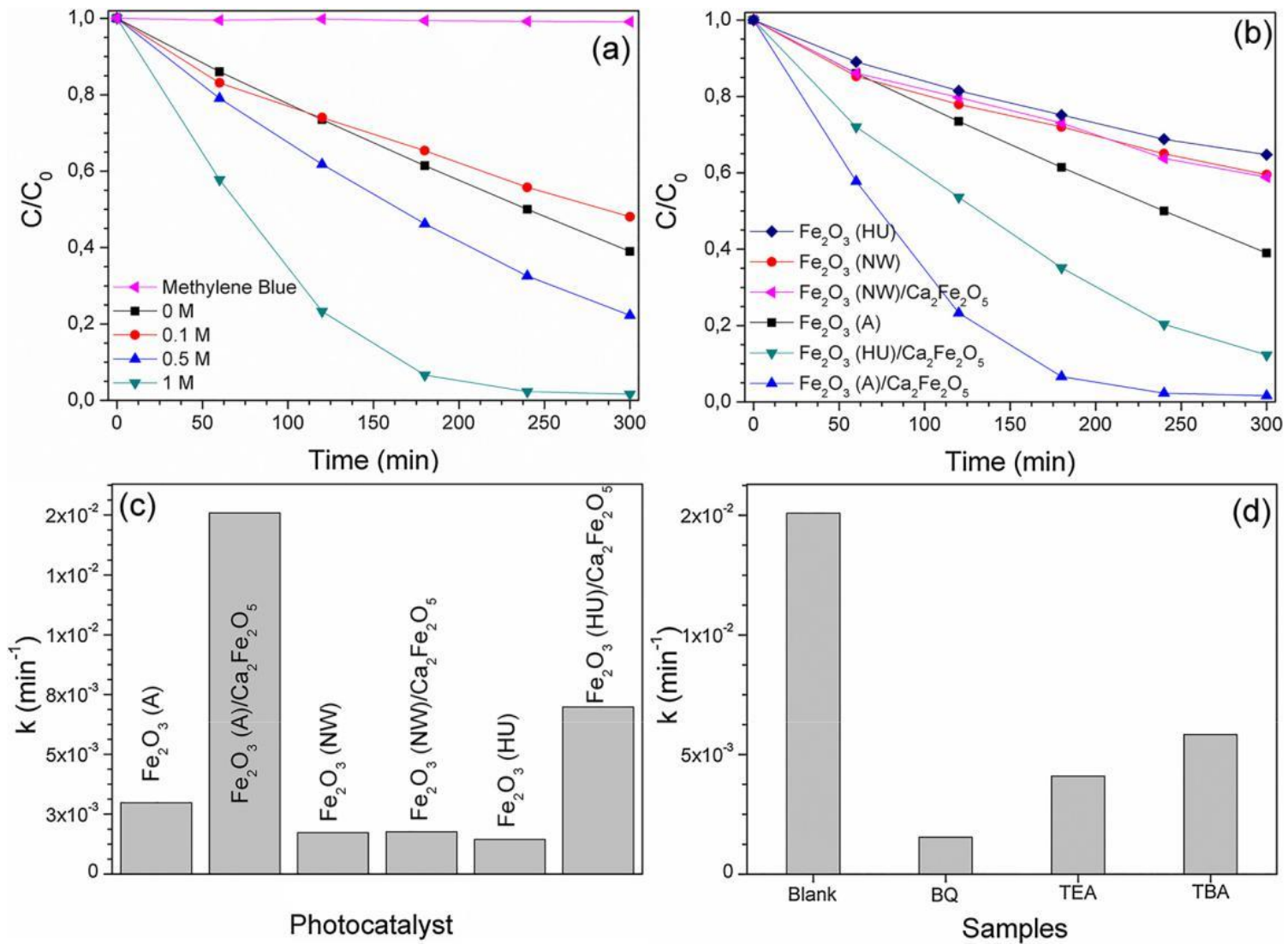

Fig. 4. The photocatalytic properties of the synthesized materials. (a) MB photocatalytic degradation in water $(10 \mathrm{mg} / \mathrm{l})$ under visible light by the $\mathrm{Fe}_{2} \mathrm{O}_{3} / \mathrm{Ca}_{2} \mathrm{Fe}_{2} \mathrm{O}_{5}$ nanoheterostructures obtained from amorphous substrate nanoparticles soaked in $\mathrm{Ca}\left(\mathrm{NO}_{3}\right)_{2}$ solutions with different molarities. (b) $\mathrm{MB}$ photocatalytic degradation by various $\mathrm{Fe}_{2} \mathrm{O}_{3} / \mathrm{Ca}_{2} \mathrm{Fe}_{2} \mathrm{O}_{5}$ nanoheterostructures obtained from the $\mathrm{Ca}\left(\mathrm{NO}_{3}\right)_{2}$ solution using different substrate nanoparticles $\left(\mathrm{Fe}_{2} \mathrm{O}_{3}(\mathrm{~A})\right.$ - amorphous iron-containing sediment, $\mathrm{Fe}_{2} \mathrm{O}_{3}(\mathrm{HU})-$ hematite obtained from hydrothermal synthesis and $\mathrm{Fe}_{2} \mathrm{O}_{3}(\mathrm{NW})-\mathrm{FeOOH}$ nanowires. (c) Pseudo-first-order rate constants (k) for the different $\mathrm{Fe}_{2} \mathrm{O}_{3} / \mathrm{Ca}_{2} \mathrm{Fe}_{2} \mathrm{O}_{5}$ nanoheterostructures. (d) Effects of a series of chemical scavengers on the MB degradation $\mathrm{k}$ : BQ $(0.1 \mathrm{mmol} / \mathrm{L})$ for scavenging $\% \mathrm{O}^{2-}$, TEA $(1 \mathrm{mmol} / \mathrm{L})$ for quenching $\mathrm{h}^{+}$, and TBA $(1 \mathrm{mmol} / \mathrm{L})$ for scavenging $\% \mathrm{OH}$ on $\mathrm{Fe}_{2} \mathrm{O}_{3}(\mathrm{~A}) / \mathrm{Ca}_{2} \mathrm{Fe}_{2} \mathrm{O}_{5}$.

3.4. Photocatalytic dye degradation by hematite and $\mathrm{Fe} 2 \mathrm{O} 3 / \mathrm{Ca} 2 \mathrm{Fe} 2 \mathrm{O} 5$ nanoheterostructure powders

The photocatalytic activities of the synthesized materials were es-timated by the degradation of methylene blue (MB) under visible-light irradiation (45 $\pm 3 \mathrm{~mW} / \mathrm{cm}^{2}$ ). The change of the most intense ab-sorption peak of $\mathrm{MB}$ centered at $665 \mathrm{~nm}$ was evaluated to study MB degradation. The blank experiments show that only a $1 \%$ decrease of $\mathrm{MB}$ occurs in the absence of a photocatalyst during a $5 \mathrm{~h}$ irradiation. $\alpha-\mathrm{Fe}_{2} \mathrm{O}_{3}$ was obtained by thermal phase transition/treatment at $820{ }^{\circ} \mathrm{C}$ for $20 \mathrm{~min}$ from: (i) amorphous $\mathrm{Fe}$ containing precipitates $\left(\alpha-\mathrm{Fe}_{2} \mathrm{O}_{3}(\mathrm{~A})\right)$,

(ii) $\alpha-\mathrm{FeOOH}$ nanowires $\left(\alpha-\mathrm{Fe}_{2} \mathrm{O}_{3}(\mathrm{NW})\right.$ ) and (iii) hydrothermal synthesis derived $\alpha-\mathrm{Fe}_{2} \mathrm{O}_{3}\left(\alpha-\mathrm{Fe}_{2} \mathrm{O}_{3}(\mathrm{HU})\right)$. The photocatalytic activities of $\alpha-\mathrm{Fe}_{2} \mathrm{O}_{3}$ were studied to estimate the enhancement in performance after coupling with $\mathrm{Ca}_{2} \mathrm{Fe}_{2} \mathrm{O}_{5}$ (Fig. 4). The pseudo-first-order rate con-stants (k) for $\mathrm{MB}$ degradation for the various hematite samples are very

similar and decrease in the following order: $\alpha-\mathrm{Fe}_{2} \mathrm{O}_{3}$ (A) $\left(2.97 \cdot 10^{-3} \mathrm{~min}^{-1}\right)$ $\rightarrow \alpha-\mathrm{Fe}_{2} \mathrm{O}_{3}(\mathrm{NW})\left(1.73 \cdot 10^{-3} \mathrm{~min}^{-1}\right) \rightarrow \alpha-\mathrm{Fe} 2 \mathrm{O} 3$

(HU) $\left(1.45 \cdot 10^{-3} \mathrm{~min}^{-1}\right)$. The observed rate constants are almost the same as those previously reported for $\mathrm{MB}$ degradation under visible-light irradiation by flower-like hierarchical nanosized $\alpha-\mathrm{Fe}_{2} \mathrm{O}_{3}$ [32].

Multipoint BET surface area measurements revealed the following specific surface area values of the hematite samples: $\alpha-\mathrm{Fe}_{2} \mathrm{O}_{3}$ (A) $(2.16$ $\left.\mathrm{m}^{2} / \mathrm{g}\right), \alpha-\mathrm{Fe}_{2} \mathrm{O}_{3}(\mathrm{NW})\left(28.84 \mathrm{~m}^{2} / \mathrm{g}\right)$ and $\alpha-\mathrm{Fe}_{2} \mathrm{O}_{3}$ (HU) $\left(12.55 \mathrm{~m}^{2} / \mathrm{g}\right)$. To exclude the effect of the specific surface area, the $\mathrm{k}$ values were divided by the surface areas. The specific rate constants for the various

samples decrease in the following order: $\alpha-\mathrm{Fe}_{2} \mathrm{O}_{3}$ (A) $\left(1.38 \cdot 10^{-3} \mathrm{~min}^{-1} \mathrm{~g}\right.$ $\left.\mathrm{m}^{-2}\right) \rightarrow \mathrm{a}-\mathrm{Fe}_{2} \mathrm{O}_{3}$ (HU) $\left(0.11 \cdot 10^{-3} \min ^{-1} \mathrm{~g} \mathrm{~m}^{-2}\right) \rightarrow$
$\mathrm{Fe}_{2} \mathrm{O}_{3}$ (NW) $\left(0.08 \cdot 10^{-3} \mathrm{~min}^{-1} \mathrm{~g} \mathrm{~m}^{-2}\right)$. The results show that $\alpha-\mathrm{Fe}_{2} \mathrm{O}_{3}$ (A) exhibits considerably higher photocatalytic activity, which is related to various surface properties. The measured $\mathrm{Z}$-potential values for the var-ious annealed samples were: $\alpha-\mathrm{Fe}_{2} \mathrm{O}_{3}(\mathrm{~A})(+23.9 \mathrm{eV}) \rightarrow \alpha-\mathrm{Fe}_{2} \mathrm{O}_{3}(\mathrm{HU})(+17.6 \mathrm{eV})$ $\rightarrow \mathrm{Fe}_{2} \mathrm{O}_{3}(\mathrm{NW})(-37.9 \mathrm{eV})$.

The $\mathrm{k}$ value increased 5.1 times for $\alpha-\mathrm{Fe}_{2} \mathrm{O}_{3}(\mathrm{~A})\left(\mathrm{k}=0.015 \mathrm{~min}^{-1}\right)$ and 4.8 times for $\alpha-\mathrm{Fe}_{2} \mathrm{O}_{3}(\mathrm{HU})\left(\mathrm{k}=0.007 \mathrm{~min}^{-1}\right)$ when the samples (before thermal treatment) were soaked in $1 \mathrm{M}$ aqueous $\mathrm{Ca}\left(\mathrm{NO}_{3}\right)_{2}$ so-lution. No enhancement was observed for the materials obtained from the $\alpha-\mathrm{FeOOH}$ substrate nanoparticles. The samples obtained from the amorphous substrate nanoparticles exhibited two-fold higher rate constants compared to the other samples. We also studied the specific surface areas to normalize the rate constants and exclude the effect of a larger surface area. The specific surface areas were $12.4 \mathrm{~m}^{2} / \mathrm{g}$ and $6.3 \mathrm{~m}^{2} / \mathrm{g}$ for $\mathrm{Fe}_{2} \mathrm{O}_{3} / \mathrm{Ca}_{2} \mathrm{Fe}_{2} \mathrm{O}_{5}$ obtained from $\alpha$ $\mathrm{Fe}_{2} \mathrm{O}_{3}(\mathrm{~A})$ and $\alpha-\mathrm{Fe}_{2} \mathrm{O}_{3}(\mathrm{HU})$, respectively. The specific rate constant for $\mathrm{Fe}_{2} \mathrm{O}_{3} / \mathrm{Ca}_{2} \mathrm{Fe}_{2} \mathrm{O}_{5}$ ob-tained from $\alpha-\mathrm{Fe}_{2} \mathrm{O}_{3}$ (A) $\left(1.21 \cdot 10^{-3} \mathrm{~min}^{-1} \mathrm{~g} \mathrm{~m}^{-2}\right)$ is still higher than those observed for the other samples but is similar to the sample ob-tained from crystalline $\alpha-\mathrm{Fe}_{2} \mathrm{O}_{3}\left(1.12 \cdot 10^{-3} \mathrm{~min}^{-1} \mathrm{~g} \mathrm{~m}^{-2}\right)$. The results show that both amorphous iron-containing nanoparticles can be used for substrate materials to obtain an efficient $\mathrm{Fe}_{2} \mathrm{O}_{3} / \mathrm{Ca}_{2} \mathrm{Fe}_{2} \mathrm{O}_{5}$ photo-catalyst nanoheterostructure. The sample obtained from the $\alpha-\mathrm{FeOOH}$ substrate nanoparticles showed a considerably lower rate constant $\left(0.034 \cdot 10^{-3} \mathrm{~min}^{-1} \mathrm{~g}\right.$ $\mathrm{m}^{-2}$ ), which could be attributed to hindered $\mathrm{Ca}_{2} \mathrm{Fe}_{2} \mathrm{O}_{5}$ formation, as discussed in the section above about the for-mation and structural properties of the $\mathrm{Fe}_{2} \mathrm{O}_{3} / \mathrm{Ca}_{2} \mathrm{Fe}_{2} \mathrm{O}_{5}$ nanoheteros-tructure powders.

The enhanced photocatalytic performance can be attributed to the 

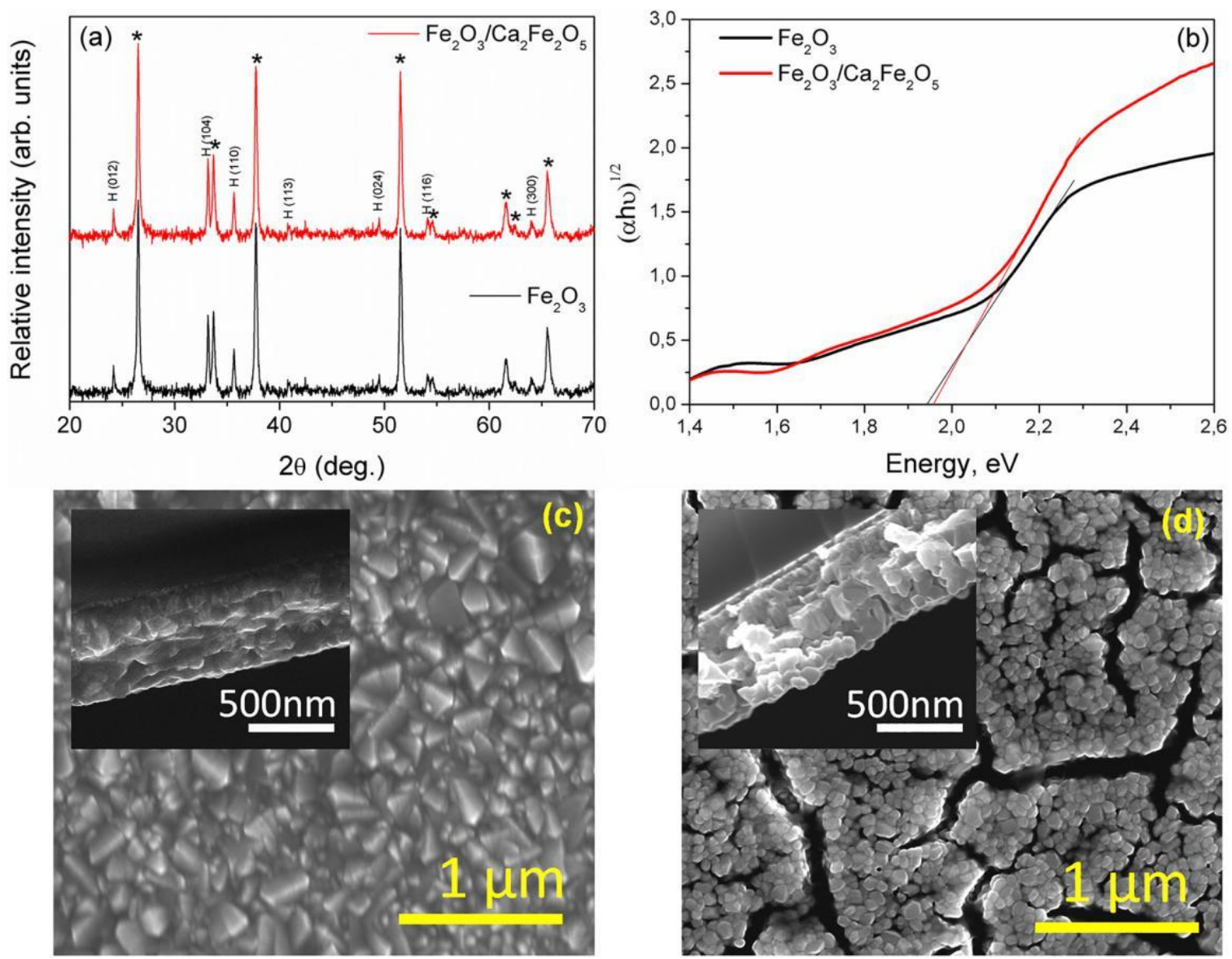

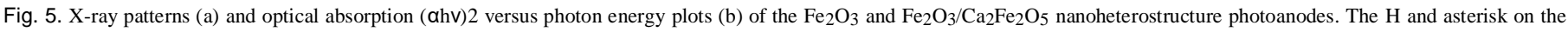

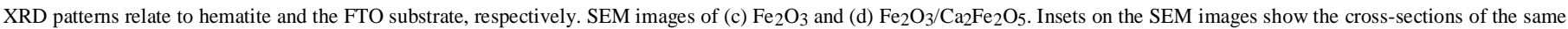
samples.

tight interface $\mathrm{Fe}_{2} \mathrm{O}_{3} / \mathrm{Ca}_{2} \mathrm{Fe}_{2} \mathrm{O}_{5}$ nanoheterostructure formation and improved photogenerated charge-carrier separation over the interface. $\mathrm{Ca}_{2} \mathrm{Fe}_{2} \mathrm{O}_{5}$ is a narrow band gap p-type semiconductor with a more-ne-gative $\mathrm{CB}$ potential and more-negative VB potential in comparison to hematite [33]. Thus, charge transfer between $n$-type $\alpha-\mathrm{Fe}_{2} \mathrm{O}_{3}$ and p-type $\mathrm{Ca}_{2} \mathrm{Fe}_{2} \mathrm{O}_{5}$ can be potentially incorporated into a Z-scheme me-chanism, where photoinduced electrons on hematite would recombine with photogenerated electron holes on $\mathrm{Ca}_{2} \mathrm{Fe}_{2} \mathrm{O}_{5}$,

leaving electrons on $\mathrm{Ca}_{2} \mathrm{Fe}_{2} \mathrm{O}_{5}$ and electron holes on $\alpha-\mathrm{Fe}_{2} \mathrm{O}_{3}$ for reduction and oxidation reactions, respectively, and consequently providing a high redox po-tential for the overall system. Z-scheme photocatalytic systems have been considered the most effective photocatalytic systems due to their excellent charge separation (reduced recombination) and high redox potentials compared to classical heterojunction-type photocatalytic systems, where electrons are transferred to the $\mathrm{CB}$ with a lower redu-cing potential, and electron holes are transferred to the VB with a lower oxidation potential [18]. In a Z-scheme, two semiconductor compounds are primarily coupled via ohmic contact (conductor) with low contact resistance [34]. The first reported all-solid Z-scheme was the three-component semiconductor-conductorsemiconductor system $\left(\mathrm{TiO}_{2}-\mathrm{Au}-\mathrm{CdS}\right)$ published in 2006 by Tada et al. [35]. Other two-component solid-state Z-scheme systems, where low contact resistance was provided by conductive contact interface [18] or a $p-n$ junction [36,37], have also been reported. Here, our Z-scheme may be formed through a p-n junction between p-type $\mathrm{Ca}_{2} \mathrm{Fe}_{2} \mathrm{O}_{5}$ and n-type $\alpha-\mathrm{Fe}_{2} \mathrm{O}_{3}$. P-type conductivity in brownmillerite $\mathrm{Ca}_{2} \mathrm{Fe}_{2} \mathrm{O}_{5}$ is provided by oxygen inter-stitials, which are charge compensated by holes associated with $\mathrm{Fe}$ cations due to variable oxidation states [38].

To verify the Z-scheme charge-transfer mechanism, various scavengers were added during the photocatalytic MB degradation tests. First, benzoquinone $(\mathrm{BQ})$ was added to scavenge superoxide anions, $\% \mathrm{O}^{2-}$. The $\mathrm{k}$ value for $\mathrm{MB}$ degradation by $\mathrm{Fe}_{2} \mathrm{O}_{3}(\mathrm{~A}) / \mathrm{Ca}_{2} \mathrm{Fe}_{2} \mathrm{O}_{5}$ decreased by an order of magnitude from $0.015\left(\mathrm{~min}^{-1}\right)$ to $0.0015\left(\mathrm{~min}^{-1}\right)$, in-dicating that $\% \mathrm{O}^{2-}$ has a considerable role in MB degradation. However, we did not observe a decrease in photocatalytic activity for bare $\mathrm{Fe}_{2} \mathrm{O}_{3}$ after $\mathrm{BQ}$ addition. The potential for oxygen reduction from $\mathrm{O}_{2}$ to $\% \mathrm{O}^{2-}$ is $-0.33 \mathrm{eV}$ vs the normal hydrogen electrode (NHE), thus $\% \mathrm{O}^{2-}$ cannot be generated by photoinduced electrons on the $\mathrm{CB}$ of he-matite, which has a reduction potential of $+0.2 \mathrm{eV}$ vs NHE [39], while the $\mathrm{CB}$ of $\mathrm{Ca}_{2} \mathrm{Fe}_{2} \mathrm{O}_{5}$ has a more-negative reduction potential than that of oxygen reduction to produce $\% \mathrm{O}^{2-}$. Therefore, $\% \mathrm{O}^{2-}$ release was ex-perimentally observed [33]. We also studied the influence of trietha-nolamine (TEA) to quench holes and tert-butyl alcohol (TBA) for scavenging hydroxyl radicals, \%OH. Both scavengers displayed an al-most equal effect on $M B$ degradation by the photocatalytic process. The rate constants for $\mathrm{MB}$ degradation over $\mathrm{Fe}_{2} \mathrm{O}_{3}(\mathrm{~A}) / \mathrm{Ca}_{2} \mathrm{Fe}_{2} \mathrm{O}_{5}$ decreased from 0.015 to 0.004 and $0.006\left(\mathrm{~min}^{-1}\right)$ with added TEA and TBA, re-spectively. The VB oxidation potential of $\alpha-\mathrm{Fe}_{2} \mathrm{O}_{3}$ is sufficiently positive to oxidize $\mathrm{H}_{2} \mathrm{O}$ to $\% \mathrm{OH}$ and $\mathrm{H}^{+}\left(\mathrm{H}_{2} \mathrm{O}+\mathrm{h}^{+} \rightarrow \% \mathrm{OH}+\mathrm{H}^{+}\right)$, where re-leased $\mathrm{H}^{+}$can generate ROS $\mathrm{H}_{2} \mathrm{O}_{2}$ and $\% \mathrm{OH}$.

\section{5. $\mathrm{Fe}_{2} \mathrm{O}_{3}$ and $\mathrm{Fe}_{2} \mathrm{O}_{3} / \mathrm{Ca}_{2} \mathrm{Fe}_{2} \mathrm{O}_{5}$ photoanodes and their PEC performances}

Photoelectrochemical (PEC) measurements were performed on the $\alpha$ $\mathrm{Fe}_{2} \mathrm{O}_{3}$ and $\mathrm{Fe}_{2} \mathrm{O}_{3} / \mathrm{Ca}_{2} \mathrm{Fe}_{2} \mathrm{O}_{5}$ photoanodes to gain better understanding of the photoinduced charge-carrier separation and transport over the nanoheterostructure. The photoanodes were obtained in a similar way as the Z-scheme $\mathrm{Fe}_{2} \mathrm{O}_{3} / \mathrm{Ca}_{2} \mathrm{Fe}_{2} \mathrm{O}_{5}$ nanoheterostructure powders - by 

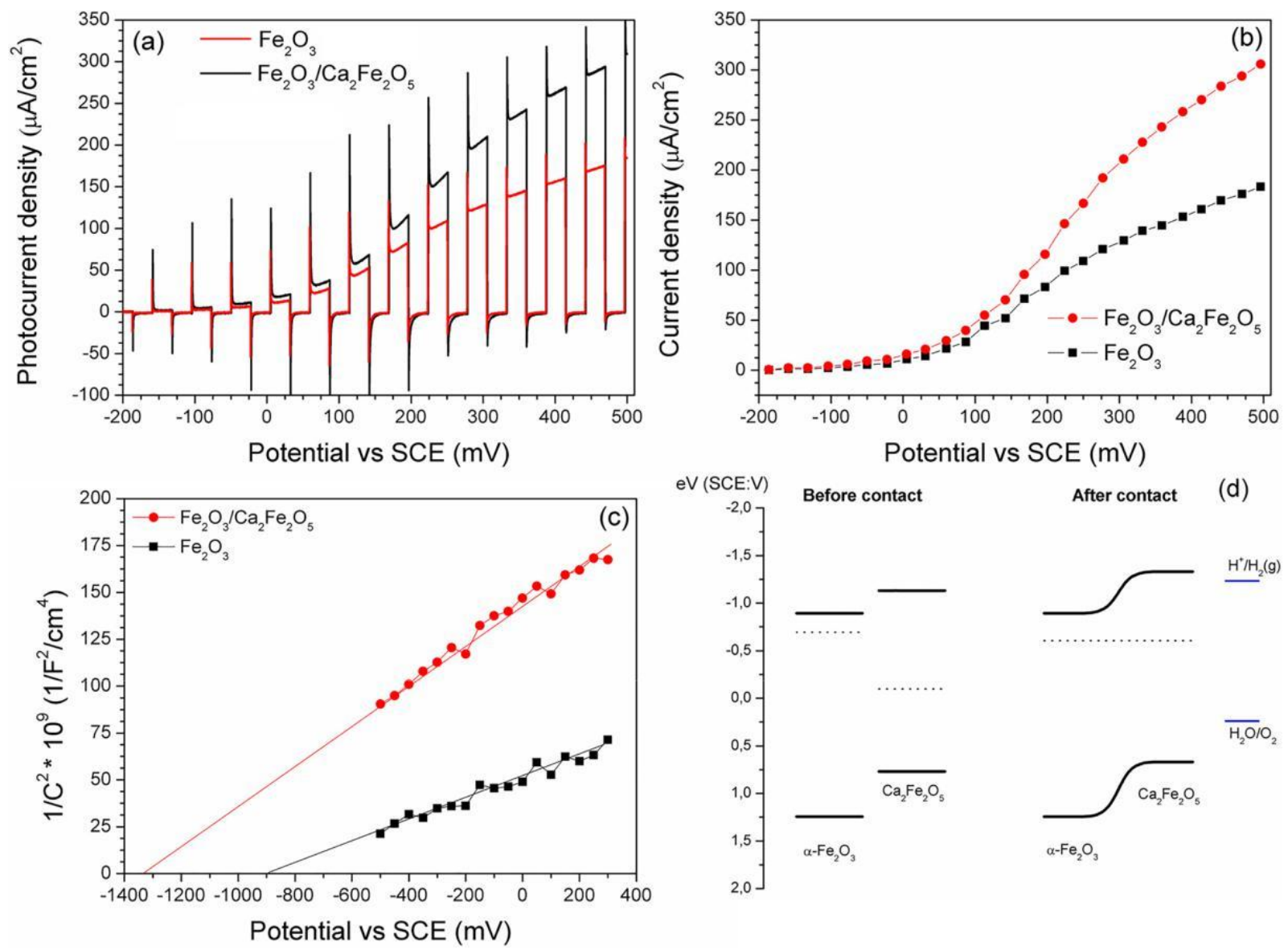

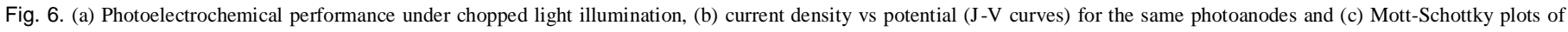

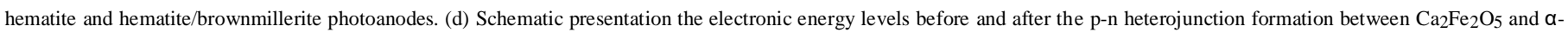
$\mathrm{Fe}_{2} \mathrm{O}_{3}$.

soaking iron-containing sediment in a $\mathrm{Ca}\left(\mathrm{NO}_{3}\right)_{2}$ solution and subse-quently drying and heating at $820^{\circ} \mathrm{C}$ for $20 \mathrm{~min}$. Iron-containing sub-strate films were prepared by potentiostatic anodic electrodeposition on F-doped $\mathrm{SnO}_{2}$ (FTO) transparent conductive oxide substrates. The uti-lized anodic deposition conditions favor the oxidation of $\mathrm{Fe}^{2+}$ to $\mathrm{Fe}^{3+}$ and precipitation of the amorphous oxyhydroxide [40]. To obtain the $\mathrm{Fe}_{2} \mathrm{O}_{3} / \mathrm{Ca}_{2} \mathrm{Fe}_{2} \mathrm{O}_{5}$ nanoheterostructure, iron-containing substrate films were immersed in a $\mathrm{Ca}\left(\mathrm{NO}_{3}\right)_{2}$ solution, dried and heat treated.

The XRD patterns, UV-vis absorption spectra and SEM images of the $\mathrm{Fe}_{2} \mathrm{O}_{3}$ and $\mathrm{Fe}_{2} \mathrm{O}_{3} / \mathrm{Ca}_{2} \mathrm{Fe}_{2} \mathrm{O}_{5}$ photoanodes are displayed in Fig. 5. The XRD patterns confirm the formation of the hematite phase. The optical band gaps of the obtained $\mathrm{Fe}_{2} \mathrm{O}_{3}$ and $\mathrm{Fe}_{2} \mathrm{O}_{3} / \mathrm{Ca}_{2} \mathrm{Fe}_{2} \mathrm{O}_{5}$ photoanodes were $1.94 \mathrm{eV}$ and 1.96 $\mathrm{eV}$, respectively. Similar to the powders (see Section 3.3.), a small blue shift was observed upon adding $\mathrm{Ca}_{2} \mathrm{Fe}_{2} \mathrm{O}_{5}$ to $\mathrm{Fe}_{2} \mathrm{O}_{3}$.

The SEM images show very different morphologies for $\mathrm{Fe}_{2} \mathrm{O}_{3}$ and the $\mathrm{Fe}_{2} \mathrm{O}_{3} / \mathrm{Ca}_{2} \mathrm{Fe}_{2} \mathrm{O}_{5}$ heterostructure. The hematite photoanode formed from tetragonal-like single crystals with edges up to $500 \mathrm{~nm}$. The het-erostructure photoanode reveals a microstructure composed of rela-tively small (70-150 $\mathrm{nm}$ ) irregularly shaped nanocrystals and cracks. The cross-sections of both films reveal very similar thicknesses of ap-proximately $850 \mathrm{~nm}$ and, again, different morphologies along the entire cross-sections, indicating that calcium nitrate was impregnated deep in the electrochemically deposited ironcontaining amorphous substrate layer. The presence of $\mathrm{Ca}_{2} \mathrm{Fe}_{2} \mathrm{O}_{5}$ in the films was confirmed by X-ray photoelectron spectroscopy (XPS) (ESI, Fig. S7). The locations and shapes of the photolines for the $\mathrm{Fe}_{2} \mathrm{O}_{3} / \mathrm{Ca}_{2} \mathrm{Fe}_{2} \mathrm{O}_{5}$ heterostructure powder coincide well with those obtained for previously reported brownmillerite $\mathrm{Ca}_{2} \mathrm{Fe}_{2} \mathrm{O}_{5}[31,41]$. The $\mathrm{Ca} 2 \mathrm{p} 3 / 2$ photo line is located at
$346.6 \mathrm{eV}$, and the $\mathrm{Fe} 2 \mathrm{p} 3 / 2$ maximum is located at $710.5 \mathrm{eV}$, with a satellite signal associated with $\mathrm{Fe}^{3+}$ also present at higher binding energies.

The PEC measurements were measured under visible light $(15 \pm 1$ $\left.\mathrm{mW} / \mathrm{cm}^{2}\right)$ in a three-electrode cell containing $1 \mathrm{M} \mathrm{NaOH}$ electrolyte $(\mathrm{pH}=$ 13), a platinum wire counter electrode, the sample film on an FTO/glass substrate as the working electrode and a saturated calomel electrode (SCE) as the reference electrode. $\mathrm{J}-\mathrm{V}$ curves for the hematite $\mathrm{Fe}_{2} \mathrm{O}_{3}$ and $\mathrm{Fe}_{2} \mathrm{O}_{3} / \mathrm{Ca}_{2} \mathrm{Fe}_{2} \mathrm{O}_{5}$ photoanodes are demonstrated in Fig. 6(b). A photocurrent of $183 \mu \mathrm{A} / \mathrm{cm}^{2}$ was observed at $0.5 \mathrm{~V}$ for bare hematite, and this photocurrent increased to $306 \mu \mathrm{A} / \mathrm{cm}^{2}$ for $\mathrm{Fe}_{2} \mathrm{O}_{3} / \mathrm{Ca}_{2} \mathrm{Fe}_{2} \mathrm{O}_{5}$. The photocurrent indicates the number of photogenerated holes that reach the semiconductor/liquid interface. The higher pho-tocurrent can be due to the increased relative volume of the space charge layer and enhanced photogenerated charge-carrier separation. Nanostructuring is an effective strategy to increase the relative volume of the space charge layer [42], while heterostructuring enhances charge-carrier separation [16,17]. Our electron microscopy observa-tions reveal a remarkable decrease in grain size for the samples im-mersed in calcium nitrate before annealing, while charge-carrier se-paration is improved in the heterostructure because both the $\mathrm{CB}$ and VB edges of hematite lie energetically lower than the $\mathrm{CB}$ and $\mathrm{VB}$ of brownmillerite. Thus, photoinduced electrons are transferred from $\mathrm{Ca}_{2} \mathrm{Fe}_{2} \mathrm{O}_{5}$ to $\mathrm{Fe}_{2} \mathrm{O}_{3}$ under applied bias and anodic conditions. Moreover, photogenerated electron holes are expected to be transferred from he-matite to brownmillerite for oxidation reactions.

The observed results correlate with the Mott-Schottky analysis based on electrochemical impedance measurements in the dark on bare $\mathrm{Fe}_{2} \mathrm{O}_{3}$ and $\mathrm{Fe}_{2} \mathrm{O}_{3} / \mathrm{Ca}_{2} \mathrm{Fe}_{2} \mathrm{O}_{5}$. The flat band potential (VFB) position was 

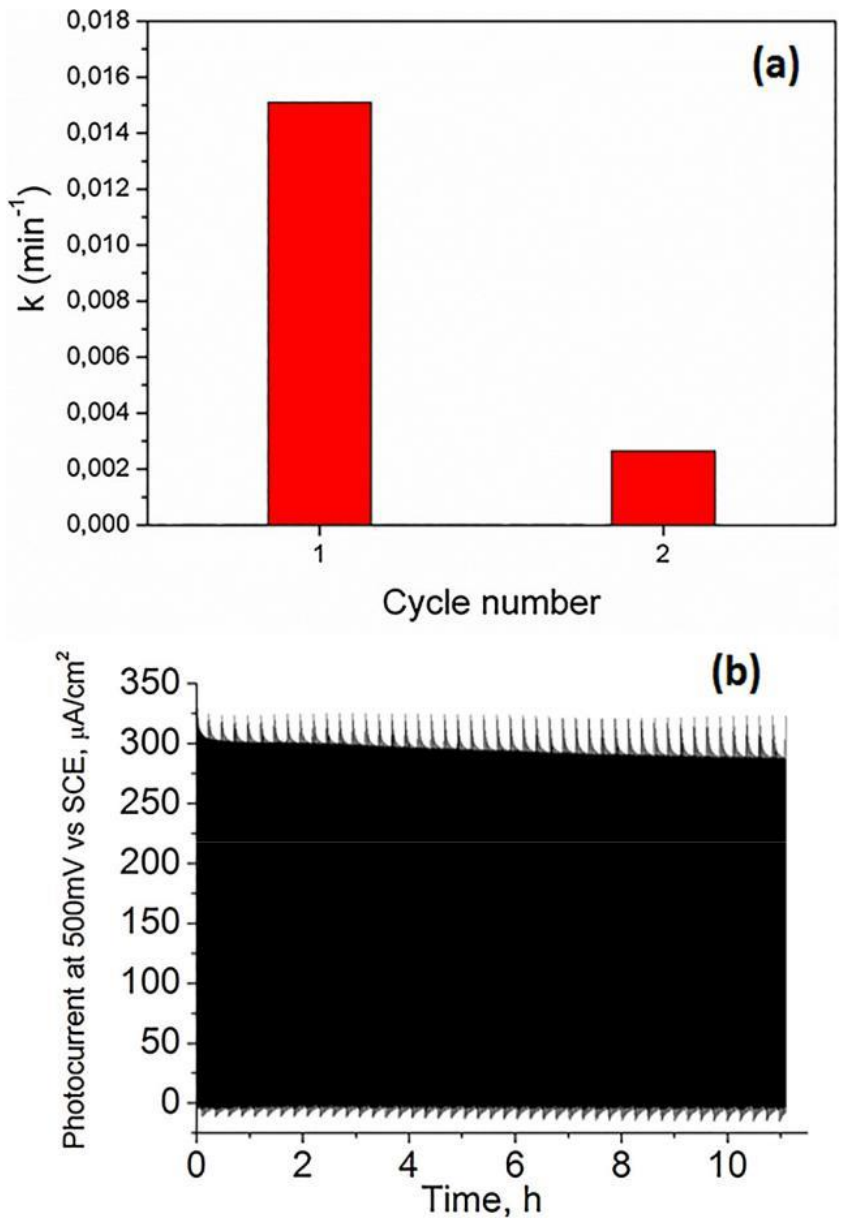

Fig. 7. (a) Graph showing the decrease of the $\mathrm{MB}$ photocatalytic degradation rate constant of the $\mathrm{Fe}_{2} \mathrm{O}_{3} / \mathrm{Ca}_{2} \mathrm{Fe}_{2} \mathrm{O}_{5}$ system under the $\mathrm{Z}$-scheme regime (duration of the first cycle was $1 \mathrm{~h}$ ). (b) Graph showing the good stability of the $\mathrm{Fe}_{2} \mathrm{O}_{3} / \mathrm{Ca}_{2} \mathrm{Fe}_{2} \mathrm{O}_{5}$ system during PEC measurements.

estimated from the capacitance at the interface between the semi-conductor and electrolyte by extrapolating the $1 / \mathrm{C}^{2}$ versus $\mathrm{V}$ plot. The observed VFB value was $-895 \mathrm{mV}$ versus SCE at $\mathrm{pH}=13$ for hematite, which is similar to those reported by others for hematite on FTO $[43,44]$. The VFB increases to $-1330 \mathrm{mV}$ when $\mathrm{Fe}_{2} \mathrm{O}_{3}$ is coupled with $\mathrm{Ca}_{2} \mathrm{Fe}_{2} \mathrm{O}_{5}$, confirming the previously suggested band alignment, which is schematically illustrated in Fig. 6(d).

\subsection{Stability of the $\mathrm{Fe}_{2} \mathrm{O}_{3} / \mathrm{Ca}_{2} \mathrm{Fe}_{2} \mathrm{O}_{5}$ heterojunction powders and} photoanodes

Finally, the photocatalytic stability of the $\mathrm{Fe}_{2} \mathrm{O}_{3} / \mathrm{Ca}_{2} \mathrm{Fe}_{2} \mathrm{O}_{5}$ system was tested under a $\mathrm{Z}$-scheme regime (powder suspension in $\mathrm{MB}$ water solution) as well as using PEC measurements. From cyclic photo-catalytic MB degradation measurements under a Z-scheme regime, we observed a five-fold rate constant decrease already at the second cycle after irradiating for only $3 \mathrm{~h}$ in the first cycle (Fig. 7(a)), while the PEC measurements showed very stable behavior with no loss of the mea-sured photocurrent over $12 \mathrm{~h}$ of visible-light irradiation (Fig. 7(b)). The observed behavior could be related to the low stability of $\mathrm{Ca}_{2} \mathrm{Fe}_{2} \mathrm{O}_{5}$ against photoreduction. In the $\mathrm{Z}$-scheme regime, photogenerated elec-trons are separated on the $\mathrm{Ca}_{2} \mathrm{Fe}_{2} \mathrm{O}_{5}$ side, thus triggering its corrosion by photoreduction. XRD of the $\mathrm{Fe}_{2} \mathrm{O}_{3} / \mathrm{Ca}_{2} \mathrm{Fe}_{2} \mathrm{O}_{5}$ powder after three photocatalytic $\mathrm{MB}$ degradation cycles shows the formation $\mathrm{CaO}$ and $\mathrm{CaFe}_{2} \mathrm{O}_{4}$ impurity phases, indicating that photogenerated occurs via the reaction $\mathrm{Ca}_{2} \mathrm{Fe}_{2} \mathrm{O}_{5} \rightarrow \mathrm{CaFe}_{2} \mathrm{O}_{4}+\mathrm{CaO}$ (ESI, Fig. S8). Carbonate forma-tion was not observed by XRD, showing that the photocorrosion mechanism of $\mathrm{Ca}_{2} \mathrm{Fe}_{2} \mathrm{O}_{5}$ in the $\mathrm{Z}$-scheme regime is different from that of bare brownmillerite, which transforms to carbonates during the pho-todegradation process of methylene orange [45].

However, the $\mathrm{Fe}_{2} \mathrm{O}_{3} / \mathrm{Ca}_{2} \mathrm{Fe}_{2} \mathrm{O}_{5}$ system is stable under PEC measurements, indicating a different charge-transfer mechanism. A similar p-n junction photoanode, where hematite was coupled with $\mathrm{CaFe}_{2} \mathrm{O}_{4}$, was demonstrated by M.G. Ahmed et al. [44]. Under illumination, photogenerated holes were transferred to $\mathrm{CaFe}_{2} \mathrm{O}_{4}$, while photo-generated electrons transferred from the $\mathrm{CaFe}_{2} \mathrm{O}_{4} \mathrm{CB}$ to the $\mathrm{Fe}_{2} \mathrm{O}_{3} \mathrm{CB}$ and further to the contact electrode. Here, under the proposed me-chanism, $\mathrm{Ca}_{2} \mathrm{Fe}_{2} \mathrm{O}_{5}$ in the $\mathrm{Fe}_{2} \mathrm{O}_{3} / \mathrm{Ca}_{2} \mathrm{Fe}_{2} \mathrm{O}_{5}$ system is protected from photocorrosion and thus exhibits stable photocurrent, as demonstrated in Fig. 7(b).

\section{Conclusions}

An all-solid-state Z-scheme nanoheterostructure was successfully constructed from an earth abundant, environmentally friendly element based on $n$ - and p-type narrow band gap semiconductors, hematite $\alpha-\mathrm{Fe}_{2} \mathrm{O}_{3}$ and brownmillerite $\mathrm{Ca}_{2} \mathrm{Fe}_{2} \mathrm{O}_{5}$, by soaking Fe-containing nano-particle substrates (free standing particles in suspensions or thin films) with $\mathrm{Ca}^{2+}$ aqueous solutions. The heterostructure formation was more pronounced on amorphous Fe nanoparticle substrates than on crystal-line hematite, while the formation of $\mathrm{Ca}_{2} \mathrm{Fe}_{2} \mathrm{O}_{5}$ was not observed on goethite $\alpha-\mathrm{FeOOH}$. In comparison with hematite, the $\mathrm{Fe}_{2} \mathrm{O}_{3} / \mathrm{Ca}_{2} \mathrm{Fe}_{2} \mathrm{O}_{5}$ nanoheterostructure exhibited a five-fold higher photocatalytic dye degradation rate and two-fold enhanced photocurrent. The Z-scheme photoinduced charge-carrier transfer mechanism in the $\mathrm{Fe}_{2} \mathrm{O}_{3} / \mathrm{Ca}_{2} \mathrm{Fe}_{2} \mathrm{O}_{5}$ powders was confirmed by chemical methods, where the photocatalytic activity was strongly influenced by $\% \mathrm{O}^{2-}$ scavengers. However, the degradation ability of $\mathrm{Fe}_{2} \mathrm{O}_{3}$ was not influenced by these scavengers. Long-term photocurrent measurements revealed the stable performance of $\mathrm{Fe}_{2} \mathrm{O}_{3} / \mathrm{Ca}_{2} \mathrm{Fe}_{2} \mathrm{O}_{5}$, while $\mathrm{Ca}_{2} \mathrm{Fe}_{2} \mathrm{O}_{5}$ was less stable under the $\mathrm{Z}$-scheme regime due to a lower tolerance against photoreduction.

\section{Acknowledgements}

Riga Technical University supported the preparation of this manu-script from the Scientific Research Project Competition for Young Researchers No. ZP 2017/8

\section{Appendix A. Supplementary data}

Supplementary data associated with this article can be found, in the online version, at https://doi.org/10.1016/j.jece.2018.04.003.

\section{References}

[1] S. Dong, J. Feng, M. Fan, Y. Pi, L. Hu, X. Han, M. Liu, J. Sun, J. Sun, Recent developments in heterogeneous photocatalytic water treatment using visible lightresponsive photocatalysts: a review, RSC Adv. 5 (2015) 14610-14630.

[2] A. Fujishima, K. Honda, Electrochemical photolysis of water at a semiconductor electrode, Nature 238 (1972) 37-38.

[3] A. Kudo, Y. Miseki, Heterogeneous photocatalyst materials for water splitting, Chem. Soc. Rev. 38 (2009) 253-278.

[4] V.L. Prasanna, R. Vijayaraghavan, Insight into the mechanism of antibacterial ac-tivity of $\mathrm{ZnO}$ : surface defects mediated reactive oxygen species even in the dark, Langmuir 31 (2015) 9155-9162.

[5] S. Rehman, R. Ullah, A.M. Butt, N.D. Gohar, Strategies of making $\mathrm{TiO}_{2}$ and $\mathrm{ZnO}$ visible light active, J. Hazard. Mater. 170 (2009) 560-569.

[6] R. Asahi, T. Morikawa, T. Ohwaki, K. Aoki, Y. Taga, Visible-light photocatalysis in nitrogen-doped titanium oxides, Science 293 (2001) 269-271.

[7] H.J. Zhang, G.H. Chen, D.W. Bahnemann, Photoelectrocatalytic materials for environmental applications, J. Mater. Chem. 19 (2009) 5089-5121.

[8] F. Dong, H.Q. Wang, Z.B.J. Wu, One-step green synthetic approach for mesoporous Cdoped titanium dioxide with efficient visible light photocatalytic activity, Phys. Chem. C 113 (2009) 16717-16723.

[9] D. Dvoranová, V. Brezová, M. Mazúr, M.A. Malati, Investigations of metal-doped titanium dioxide photocatalysts, Appl. Catal. B: Environ. 37 (2002) 91-105.

[10] F. Dong, S. Guo, H. Wang, X. Li, Z. Wu, Enhancement of the visible light photocatalytic activity of $\mathrm{C}$-doped $\mathrm{TiO}_{2}$ nanomaterials prepared by a green synthetic 
approach, J. Phys. Chem. C 115 (2011) 13285-13292.

[11] S. Tokunaga, H. Kato, A. Kudo, Selective preparation of monoclinic and tetragonal $\mathrm{BiVO}_{4}$ with scheelite structure and their photocatalytic properties, Chem. Mater. 13 (2001) 4624-4628

[12] W. Morales, M. Cason, O. Aina, N.R. de Tacconi, K. Rajeshwar, Combustion synthesis and characterization of nanocrystalline $\mathrm{WO}_{3}, \mathrm{~J}$. Am. Chem. Soc. 130 (2008) 6318-6319.

[13] B. Ahmmad, K. Leonard, Md.S. Islam, J. Kurawaki, M. Muruganandham, T. Ohkubo, Y. Kuroda, Green synthesis of mesoporous hematite $\left(\alpha-\mathrm{Fe}_{2} \mathrm{O}_{3}\right)$ nanoparticles and their photocatalytic activity, Adv. Powder Technol. 24 (2013) 160-167.

[14] C. Yu, G. Li, S. Kumar, K. Yang, R. Jin, Phase transformation synthesis of novel $\mathrm{Ag}_{2} \mathrm{O} / \mathrm{Ag}_{2} \mathrm{CO}_{3}$ heterostructures with high visible light efficiency in photocatalytic degradation of pollutants, Adv. Mater. 26 (26) (2014) 892-898.

[15] L. Huang, F. Peng, H. Yu, H. Wang, Preparation of cuprous oxides with different sizes and their behaviors of adsorption, visible-light driven photocatalysis and photocorrosion, Solid State Sci. 11 (2009) 129-138.

[16] H. Wang, L. Zhang, Z. Chen, J. Hu, S. Li, Z. Wang, J. Liu, X. Wang, Semiconductor heterojunction photocatalysts: design, construction, and photocatalytic perfor-mances, Chem. Soc. Rev. 43 (2014) 5234-5244.

[17] H. Li, Y. Zhou, W. Tu, J. Ye, Z. Zou, State-of-the-art progress in diverse heterostructured photocatalysts toward promoting photocatalytic performance, Adv. Funct. Mater. 25 (2015) 998-1013.

[18] P. Zhou, J. Yu, M. Jaroniec, All-solid-state Z-scheme photocatalytic systems, Adv. Mater. 26 (2014) 4920-4935.

[19] H. Li, W. Tu, Y. Zhou, Z. Zou, Z-scheme photocatalytic systems for promoting photocatalytic performance: recent progress and future challenges, Adv. Sci. 3 (2016) 1500389.

[20] L.J. Zhang, S. Li, B.K. Liu, D.J. Wang, T.F. Xie, Highly efficient CdS/WO3 photocatalysts: Z-scheme photocatalytic mechanism for their enhanced photocatalytic $\mathrm{H}_{2}$ evolution under visible light, ACS Catal. 4 (2014) 3724-3729.

[21] W.K. Jo, T. Adinaveen, J.J. Vijaya, N.C.S. Selvam, Synthesis of MoS2 nanosheet supported Z-scheme $\mathrm{TiO}_{2} / \mathrm{g}_{-} \mathrm{C}_{3} \mathrm{~N}_{4}$ photocatalysts for the enhanced photocatalytic degradation of organic water pollutants, RSC Adv. 6 (2016) 10487-10497.

[22] J.-C. Wang, H. -Ch. Yao, Z.-Y. Fan, L. Zhang, J.-S. Wang, S.-Q. Zang, Z.-J. Li, Indirect Z-scheme $\mathrm{BiOI} / \mathrm{g}-\mathrm{C} 3 \mathrm{~N} 4$ photocatalysts with enhanced photoreduction $\mathrm{CO} 2$ activity under visible light irradiation, ACS Appl. Mater. Interfaces 8 (2016) 3765-3775.

[23] K.J. McDonald, K.-S. Choi, Synthesis and photoelectrochemical properties of $\mathrm{Fe}_{2} \mathrm{O}_{3} /$ $\mathrm{ZnFe}_{2} \mathrm{O}_{4}$ composite photoanodes for use in solar water oxidation, Chem. Mater. 23 (2011) 4863-4869.

[24] L. Li, P.A. Salvador, G.S. Rohrer, Photocatalysts with internal electric fields, Nanoscale 6 (2014) 24-42.

[25] P.G. Vekilov, The two-step mechanism of nucleation of crystals in solution, Nanoscale 2 (2010) 2346-2357.

[26] J. van Embden, A.S.R. Chesman, J.J. Jasieniak, The heat-up synthesis of colloidal nanocrystals, Chem. Mater. 27 (2015) 2246-2285.

[27] J.P. Jolivet, C. Chaneac, E. Tronc, Iron oxide chemistry. From molecular clusters to extended solid networks, Chem. Commun. 10 (2004) 481-483.

[28] D.M. Sherman, Electronic spectra of $\mathrm{Fe}^{3+}$ oxides and oxide hydroxides in the near IR to near UV, Am. Miner. 70 (1985) 1262-1269.

[29] A.B. Murphy, Band-gap determination from diffuse reflectance measurements of semiconductor films, and application to photoelectrochemical water-splitting, Sol. Energy Mat. Sol. C 91 (2007) 1326-1337.

[30] K. Sivula, F. Le Formal, M. Grätzel, Solar water splitting: progress using hematite ( $\left(\mathrm{aFe}_{2} \mathrm{O}_{3}\right)$ photoelectrodes, ChemSusChem 4 (2011) 432-449.

[31] C.P. Jijil, M. Lokanathan, S. Chithiravel, C. Nayak, D. Bhattacharyya, S.N. Jha, P.D. Babu, B. Kakade, R. Nandini Devi, N doping in oxygen deficient $\mathrm{Ca}_{2} \mathrm{Fe} 2 \mathrm{O} 5$ : a strategy for efficient oxygen reduction oxide catalysts, ACS Appl. Mater. Interfaces 8 (2016) 34387-34395.

[32] S. Zhang, J. Li, H. Niu, W. Xu, J. Xu, W. Hu, X. Wang, Visible-light photocatalytic degradation of methylene blue using $\mathrm{SnO}_{2} / \mathrm{a}-\mathrm{Fe}_{2} \mathrm{O}_{3}$ hierarchical nanoheteros-tructures, ChemPlusChem 78 (2013) 192-199.

[33] Y. Wang, Y. Wang, Y. Gao, Photocatalytic $\mathrm{H}_{2}$ evolution from water in the presence of carbon dioxide over $\mathrm{NiO} / \mathrm{Ca}_{2} \mathrm{Fe}_{2} \mathrm{O}_{5}$, React. Kinet. Mech. Cat. 99 (2010) 485-491.

[34] H. Li, H. Yu, X. Quan, S. Chen, Y. Zhang, Uncovering the key role of the Fermi level of the electron mediator in a Z-scheme photocatalyst by detecting the charge transfer process of $\mathrm{WO}_{3}$-metal-gC $\mathrm{g}_{3} \mathrm{~N}_{4}$ (metal $\mathrm{Cu}, \mathrm{Ag} \mathrm{Au}$ ), ACS Appl. Mater. Interfaces 8 (2016) 21112119.

[35] H. Tada, T. Mitsui, T. Kiyonaga, T. Akita, K. Tanaka, All-solid-state Z-scheme in CdS$\mathrm{Au}-\mathrm{TiO} 2$ three-component nanojunction system, Nat. Mat. 5 (2016) 782-786.

[36] N. Srinivasan, E. Sakai, M. Miyauchi, Balanced excitation between two semi-conductors in bulk heterojunction Z-scheme system for overall water splitting, ACS Catal. 6 (2016) 2197-2200.

[37] J.-C. Wang, L. Zhang, W.-X. Fang, J. Ren, Y.-Y. Li, H.-C. Yao, J.-S. Wang, Z.-J. Li, Enhanced photoreduction $\mathrm{CO}_{2}$ activity over direct $\mathrm{Z}$-scheme $\alpha-\mathrm{Fe}_{2} \mathrm{O}_{3} / \mathrm{Cu}_{2} \mathrm{O}$ heterostructures under visible light irradiation, ACS Appl. Mater. Interfaces 7 (2015) 86318639.

[38] E. Asenath-Smith, I.N. Lokuhewa, S.T. Misture, D.D. Edwards, p-Type thermo-electric properties of the oxygen-deficient perovskite $\mathrm{Ca}_{2} \mathrm{Fe}_{2} \mathrm{O}_{5}$ in the brownmil-lerite structure, J. Solid State Chem. 183 (2010) 1670-1677.

[39] A. Hellman, R.G.S. Pala, First-principles study of photoinduced water-splitting on Fe2O3, J. Phys. Chem. C 115 (2011) 12901-12907.

[40] R.L. Spray, K.-S. Choi, Photoactivity of transparent nanocrystalline $\mathrm{Fe}_{2} \mathrm{O}_{3}$ electrodes prepared via anodic electrodeposition, Chem. Mater. 21 (2009) 3701-3709.

[41] S. Dhankhar, K. Gupta, G. Bhalerao, N. Shukla, M. Chandran, B. Francis, B. Tiwari, K. Baskara, S. Singh, Anomalous room temperature magnetoresistance in brown-millerite $\mathrm{Ca}_{2} \mathrm{Fe}_{2} \mathrm{O} 5$, RSC Adv. 5 (2015) 92549-92553.

[42] S.D. Tilley, M. Cornuz, K. Sivula, M. Grätzel, Light-induced water splitting with hematite: improved nanostructure and iridium oxide catalysis, Angew. Chem. Int. Ed. 122 (2010) 6549-6552.

[43] Y.-K. Hsu, Y.-C. Chen, Y.-G. Lin, Novel $\mathrm{ZnO} / \mathrm{Fe}_{2} \mathrm{O}_{3}$ core-shell nanowires for photoelectrochemical water splitting, ACS Appl. Mater. Interfaces 7 (2015) $14157-14162$

[44] M.G. Ahmed, T.A. Kandiel, A.Y. Ahmed, I. Kretschmer, F. Rashwan, D. Bahnemann, Enhanced photoelectrochemical water oxidation on nanostructured hematite pho-toanodes via $\mathrm{p}-\mathrm{CaFe}_{2} \mathrm{O}_{4} / \mathrm{n}-\mathrm{Fe}_{2} \mathrm{O}_{3}$ heterojunction formation, J. Phys. Chem. C 119 (2015) 58645871.

[45] Y. Yang, Z. Cao, Y. Jiang, L. Liu, Y. Sun, Photoinduced structural transformation of $\mathrm{SrFeO}_{3}$ and $\mathrm{Ca}_{2} \mathrm{Fe}_{2} \mathrm{O}_{5}$ during photodegradation of methyl orange, Mater. Sci. Eng. B 132 (2006) $311-314$ 